\title{
Bioaccumulation of polycyclic aromatic hydrocarbons, histopathological alterations and parasito-fauna in bentho-pelagic host from Snake Island, Lagos, Nigeria
}

Bamidele Akinsanya ${ }^{1 *}$, Sunday A. Adebusoye ${ }^{2}$, Tamunoipirinye Alinson ${ }^{2}$ and Uche D. Ukwa ${ }^{3}$

\begin{abstract}
Objective: This study investigates the bioaccumulation of polycyclic aromatic hydrocarbons, trophic microbial biomass, parasite prevalence, antioxidant enzyme responses and histological alterations in assessing anthropogenic impacts in Snake Island, Lagos, Nigeria.

Methods: Two sample locations were chosen based on the type and nature of human activities: llase (fishing-based) and Ibasa (petroleum industry-based) communities. Fifteen PAH congeners were analysed from water, sediment, benthic invertebrates, three species of bentho-pelagic fishes and their parasito-fauna using GC/FID. Also, estimated from these samples were trophic microbial biomass, stress enzymes and histopathological alteration index of the fish gill.

Results: A significant proportion of PAHs was found in sediments originating from llase and Ibasa communities compared to all other samples analysed. Percentage distribution in the various compartments of the former was water, 2.67\%; sediment, 91.28\%; benthos, 1.19\%; fish, 3.15\%; and parasite, 1.71\%. The corresponding PAH values obtained for Ibasa were $57.83 \%, 40.07 \%, 0.00 \%, 0.01 \%$ and $0.01 \%$ respectively for water, sediment, benthos, fish, and parasite. Biota-sediment accumulation factor (BSAF) for benthos, fish, and parasite were 0.01, 0.03 and 0.02, respectively, whereas the proportions of hydrocarbon utilizing bacteria in both sediment and water columns of Ilase were $0.18 \%$ and $17.6 \%$, respectively, and those obtained from Ibasa were $0.001 \%$ and $0.03 \%$. Among the PAH residues, naphthalene had the highest concentration. Ibasa had greater hydrocarbon utilizers and parasitic protozoa prevalence. This location had higher gill-induced malondialdehyde, catalase, glutathione peroxidase, glutathione and glutathione S-transferase. Also, it showed greater Histopathological Alteration Index (HAl) of 28.0 compared to llase community with HAl of 11.0. Generally, the sum of PAH concentrations in the sediment and water columns in both study sites fell within the EPA regulated limit ( $<1000 \mathrm{ng} / \mathrm{g}$ ).

Conclusion: This indicates that the sediment and water on both sites were of moderate ecological risk. PAH residues accumulated in sediments, as well as in benthic invertebrates, get into bentho-pelagic host food chain and food webs; these could pose a significant risk to human health. As a result of this, continuous monitoring is highly advised.
\end{abstract}

Keywords: Polycyclic aromatic hydrocarbon, Biota-sediment accumulation factor, Chromatography, Histopathological alterations

\footnotetext{
* Correspondence: bamidemidele992@gmail.com

${ }^{1}$ Parasitology and Bioinformatics Unit, Department of Zoology, University of

Lagos, Akoka, Nigeria

Full list of author information is available at the end of the article
} 


\section{Background}

There is an increasing concern about environmental pollution of coastal ecosystems, as they are considered to be the most sensitive areas for the accumulation of toxic compounds because of the huge amount of anthropogenic discharge from human and industrial activities. The most important classes of environmental pollutants in the coastal area are the polycyclic aromatic hydrocarbons (PAHs) (Botello, Calva, \& Ponce-Velez, 2001; Boonyatumanond, Murakami, Wattayakorn, Togo, \& Takada, 2007; Gaspare, Machiwa, Mdachi, Streck, \& Brack, 2009). They are found everywhere, derived from mainly anthropogenic sources (Woodhead, Law, \& Matthiessen, 1999). PAHs are found in the coastal waters either as a result of accidental oil spillage or through human discharge of petroleum byproducts (petrogenic source) (Mascarelli, 2010; Redondo \& Platonov, 2009) or through combustion of fuel and other organic substances (pyrogenic source) (Lang \& Buffleb, 1964; Wakeham, Schaffner, \& Giger, 1980) or natural processes (Hites, Laflamme, \& Windsor Jr., 1980).

The pyrogenic PAHs are of larger ring systems than the petrogenic PAHs. Most of them are naturally present in crude oil (Feng \& Pisula, 2009; Laughlin \& Neff, 1979; Harvey, 1996), coal (Harvey, 1996; Achten \& Hofmann, 2010) and these compounds are referred to as petrogenic PAHs. PAHs enters the water primarily from sewage, runoff from roads (Durand, Ruban, \& Amblès, 2004), the smelter industry (Beyer, Borgenvik, \& Ravn, 1998; Næs \& Oug, 1998; Smith \& Levy, 1990) and oil spills (Mascarelli, 2010; Redondo \& Platonov, 2009), and produced water discharge from offshore oil installations (Røe Utvik, 1999). Research on PAHs concentration in the environment has received much attention by scientists, and regulators due to their persistent and toxic properties (IARC, 1983; NRC, 1983). They accumulate in sediments, aquatic pelagic and benthic food webs and pose a risk to human health (Baumard et al., 1998; Law \& Klungsoyr, 2000; Abdolahpur Monikh, Hosseini, Kazemzadeh Khoel, \& Ghasemi, 2014; Ayola, Olorunsanmi, \& Oke, 2017).

Fish are exposed to varieties of organic contaminants and one such as polycyclic aromatic hydrocarbons can be absorbed through the gills, skin, or alimentary ducts (Banaee, Mirvagefei, \& Amiri, 2008). The contaminants can cause biochemical and physiological effects on sensitive organs (Banaee et al., 2008). Also, may reduce immunological capabilities of fish host, rendering them more susceptible to parasites. Fish parasitic fauna has shown high sensitivity to toxic organic contaminants, fish parasitic protozoans and metazoans have been used as early indicators of aquatic contamination, (Palm, 2011, Sures, 2004; Abdel-Ghaffar et al., 2015a; AbdelGaber, Abdel-Ghaffar, Bashtar, Morsy, \& Saleh, 2016). Parasitic infestation indicates poor quality of the water since it increases in more polluted waters (Poulin, 1992; Avenant-Oldewage, 2001). The intestinal macro-parasites are mostly exposed to organic contaminants locked up in the host food chain, while the ecto-parasites are directly exposed to large range of them in the water medium. During pollution impact on host population, the endoparasites increase in intensity due to the host distracted immune response as a result of host energy put in fighting multiple-stress (Poulin, 1992; Avenant-Oldewage, 2001; Abdel-Gaber et al., 2015b). Carlander (1969) had reported correlation between nutrition, disease, contaminants and their effects on fish condition. Once contaminants directly or indirectly affect host condition, it could cause changes in parasite population dynamics either through reduction in relative abundance of intermediate host or free-living stage of the parasites.

Intestinal parasites, choice of micro-habitat, as survival strategy for host extrinsic stress, are still faced by intrinsic challenges, that is, host immunity. Studies have reported that gastrointestinal nematodes of fish and mammals are capable of producing superoxide dismutase (SOD) in order to reduce oxygen radical formation during stress in their host (Dzik, 2006). Effective protection of an invading parasite from host produced reactive oxidative species (ROS) depends on levels of scavenger enzymes in the parasites (Dzik, 2006). Nippostrongylus brasiliensis infection in rat showed that increased production of SOD, catalase (CAT) and glutathione peroxidase (GPX) is correlated with persistence in the host (Dzik, 2006). In addition, glutathione S-transferase (GSTs) have been suggested as the biochemical systems that protect cestodes against the host's immune attack (Brophy \& Pritchard, 1992). Parasites can induce histopathological alteration at the site of infestation as well as the contaminants at the targeted site of toxic action or sometimes as a localized toxic effect (Riggs, Lemly, \& Esch, 1987; Munkittrick \& Dixon, 1998; Lafferty, 1997; Hecker \& Karbe, 2005; Ukwa, 2012; Akinsanya, Ukwa, \& Hassan, 2014; Akinsanya, Kuton, Oyebola, Saliu, \& Ukwa, 2015). PAHs have been reported to cause structural damage to fish tissues (Correa \& Gracia, 1990) increase the prevalence of parasitic protozoa infection (Hecker \& Karbe, 2005) and decrease helminth infestation (Akinsanya et al., 2014, 2015). Histopathological and biochemical alterations in fish, microbial biomass such as hydrocarbon and non-hydrocarbon utilizers, and population dynamics of parasito-fauna could be used as bioindicators of polycyclic aromatic hydrocarbon contamination (Pothuluri \& Cerniglia, 1994; Sures, 2004; Palm, 2011; Abdelsalam et al., 2015).

\section{Study area}

The study sites lie between Ibasa (lat. 6 $6^{\circ} 25^{\prime} 37.56^{\prime \prime}$, long. $3^{\circ} 15^{\prime} 31.32^{\prime \prime}$ ) and Ilase creeks (lat. 6 24' 43.2", 
long. $\left.3^{\circ} 17^{\prime} 32.28^{\prime \prime}\right)$ in Snake Island, located within the Apapa axis of Lagos Lagoon. The island is a coastal terrain and is surrounded by rural and urban development, only accessible by boats. Reports have shown that there has been an increase in the discharge of domestic, municipal and industrial effluents, as well as contaminants associated with sand mining, oil and gas industrial tank farms and shipping activities, threatening the ecosystem services that Lagos Lagoon provides (Balogun, Ladigbolu, \& Ariyo, 2011; Amaeze, Egonmwan, Jolaoso, \& Otitoloju, 2012; Alani, Drouillard, Olayinka, \& Alo, 2012; Sogbanmu et al., 2016) Ajagbe et al. (2012) recommended the need for more studies to establish the state of pollution in the Lagos Lagoon and the levels of pollutants that are detrimental to the ecosystem health and to humans due to the consumption of contaminated fish. Department of Petroleum Resources (DPR) has described Lagos Lagoon as an important economic and sensitive estuarine ecosystem. There is currently no much information on the impact of petroleum industry-based activities in the Snake Island on the estuarine ecosystem. The choice of four sampling points was based on the nearness to the settlement and industrial activities of petroleum companies located therein. Two factors, namely freshwater discharge from the rivers and tidal seawater incursion, influence the biological, physical and chemical characteristics of the Snake Island waters. Ibasa community is characterized by the presence of various tank farms of petroleum industries located along its axis. There are about 15 tank farms of petroleum industries opposite the Ibasa community. There are four petroleum company tank farms situated within the Ibasa community. Ilase and Ibasa communities are basically residential characterized by fishing and small-time farming activities. The map of the study sites and sampling stations is shown in Fig. 1.

The aim of this study is to estimate the distribution of the PAH congeners, grouped molecular sizes and carcinogenic potentials along the food chain in the biotaand parasito-fauna in both communities. The study is to compare ecological stress in both communities based on the presence of petroleum industry-based activities. This study further uses integrated approach in monitoring multi-stressors associated with $\mathrm{PAH}$ in estuarine environment.

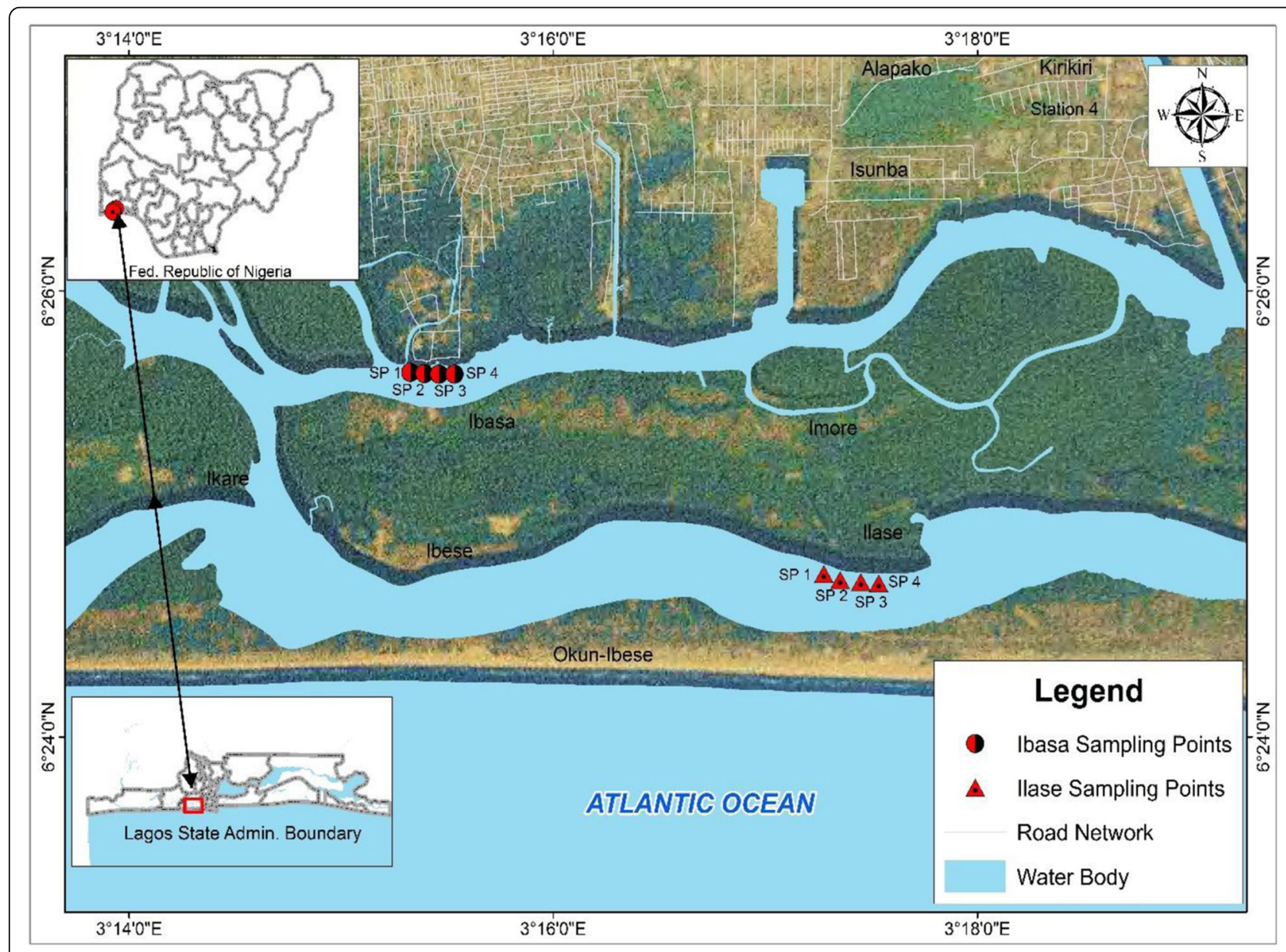

Fig. 1 Map showing the study site and sampling locations 


\section{Methods}

\section{Physico-chemical parameters measurement}

Due to the tidal currents consisting of flood and ebb currents, which arrive from the southwest, attain average speeds of $0.2 \mathrm{~m} / \mathrm{s}$ and $0.4 \mathrm{~m} / \mathrm{s}$, respectively; water collection was carried out to consider the parameter alteration that could result from this. Surface and bottom ( $2 \mathrm{ft}$ deep) water samples were collected to prepare composite samples. Collection of four composite water samples from four locations from each of the two stations (Ibasa and Ilase communities' water media) was done using Van Dorn sampler and 11 water sampling bottles (Table 1 ). The bottles were then preserved in a plastic container overlaid with ice and taken to the laboratory for further analysis. Some parameters, such as salinity, dissolved oxygen, conductivity, biochemical oxygen demand (BOD) and temperature, were measured in situ using a handheld multi-parameter probe (Horiba Water Checker Model U-10). Out of each four water samples, two were selected randomly for analysis.

\section{Water quality parameters}

Phosphate The surface water phosphate-phosphorus was determined using the ascorbic acid method. A mixture was prepared by mixing $1 \%$ ammonium molybdate in $2 \mathrm{M} \mathrm{H}_{2} \mathrm{SO}_{4}$ and hydrazine sulphate $0.1 \%$ (or $\mathrm{SnCl}_{2}$ and ascorbic acid immediately before use). The resulting solution $\mathrm{PO}_{4} / \mathrm{mg} / \mathrm{ml}$ of $4.39 \mathrm{KH}_{2} \mathrm{PO}_{2}$ (dried at $110{ }^{\circ} \mathrm{C}$ ) was dissolved in distilled water. The $1 \mathrm{ml} \mathrm{CHCl}$ added was further diluted to $1 \mathrm{l}$ of distilled water. Ten to twenty-five millilitres of the sample was acidified with nitric acid, and $25 \mathrm{ml}$ of the reagent was added. The absorbance was read off using $780 \mathrm{~nm}$.

Nitrate Surface water nitrate-nitrogen was determined gravimetrically. Twenty millilitres of the water sample was added to $1 \mathrm{ml}$ of freshly prepared $0.3 \%$ sodium salicylate. The mixture was then evaporated in a bath and thereafter left to cool. On cooling, $2 \mathrm{ml}$ sulphuric acid

Table 1 Map showing the study site and sampling locations

\begin{tabular}{llll}
\hline S/N & Latitude & Longitude & Station \\
\hline 1 & $6^{\circ} 25^{\prime} 37.56^{\prime \prime}$ & $3^{\circ} 15^{\prime} 19.44^{\prime \prime}$ & SP 1 IBASA \\
2 & $6^{\circ} 25^{\prime} 37.56^{\prime \prime}$ & $3^{\circ} 15^{\prime} 23.04^{\prime \prime}$ & SP 2 IBASA \\
3 & $6^{\circ} 25^{\prime} 37.56^{\prime \prime}$ & $3^{\circ} 15^{\prime} 27.36^{\prime \prime}$ & SP 3 IBASA \\
4 & $6^{\circ} 25^{\prime} 37.56^{\prime \prime}$ & $3^{\circ} 15^{\prime} 31.32^{\prime \prime}$ & SP 4 IBASA \\
5 & $6^{\circ} 24^{\prime} 43.2^{\prime \prime}$ & $3^{\circ} 17^{\prime} 16.44^{\prime \prime}$ & SP 1 ILASE \\
6 & $6^{\circ} 24^{\prime} 41.4^{\prime \prime}$ & $3^{\circ} 17^{\prime} 20.76^{\prime \prime}$ & SP 2 ILASE \\
7 & $6^{\circ} 24^{\prime} 40.68^{\prime \prime}$ & $3^{\circ} 17^{\prime} 26.88^{\prime \prime}$ & SP 3 ILASE \\
8 & $6^{\circ} 24^{\prime} 40.68^{\prime \prime}$ & $3^{\circ} 17^{\prime} 32.28^{\prime \prime}$ & SP 4 ILASE \\
\hline
\end{tabular}

was added for $10 \mathrm{~min}$; the solution was then washed with $25 \mathrm{ml}$ of distilled water into a calorimetric cylinder. Seven millilitres of alkaline reagent $(30 \% \mathrm{NaOH}$ and $60 \%$ Rochelle salt) was added. Next, the solution was made up to $50 \mathrm{ml}$ by adding distilled water. The yellow colour developed was matched with the prepared standards using a calorimeter at $420 \mathrm{~nm}$. The nitrate content was recorded in milligrams per litre.

\section{Sediment collection and analysis}

Four sediment samples were collected with the aid of Van Veen grab at each station and stored immediately in a polythene bag. Sediments collected were stored at $4{ }^{\circ} \mathrm{C}$ in an icebox and taken to the laboratory. Out of each four sediment samples, two were selected randomly for analysis. The selected sediment samples were separately air-dried in a laboratory. When dried, it was homogenized and sieved to remove big particulates of sediment; samples were then digested as follows: $5 \mathrm{~g}$ of the powdered sediment samples were weighed into a 100-ml beaker; $15 \mathrm{ml}$ of a freshly prepared mixture of $\mathrm{HNO}_{3} / \mathrm{H}_{2} \mathrm{O}_{2}$ ratio $1: 1$ were added to each sample and covered with a wash glass. It was allowed to stand for 30 min during which the initial reaction subsided. Digestion was carried out on a hot plate whose temperature was allowed to rise gradually until it reached a maximum temperature of $160{ }^{\circ} \mathrm{C}$ in a fume cupboard. Heating was continued for about $2 \mathrm{~h}$, reducing the volume in the beaker to about 2-5 $\mathrm{ml}$. The beaker and its contents were allowed to cool, and the content was transferred with Whatman filtration into a 50 -ml volumetric flask and made up to mark with distilled water (FAO/SIDA, 1986).

\section{Fish and benthos sampling and preservation}

Different species of fish of varying sizes from small to big, three samples each, Sarotherodon melanotheron, Mugilis cephalus, Chrysichthys nigrodigitatus, Penaeus notialis (shrimp), Macrobrachium vouenhoevenii (prawn) and Callinectes amnicola (crab) were collected with the assistance from fishermen at each station. The weight and lengths were measured. Fish samples were immediately dissected, and the organs were collected. Each labelled individually with a paper tape according to their location and kept in a cooler containing ice and preserved below $-10{ }^{\circ} \mathrm{C}$ prior to $\mathrm{PAH}$ and microbial analysis.

\section{Sample extraction and analysis}

The extraction method was carried out employing the modified methods of ASTM D3328 and ASTM 3415. This method has been used by Durand et al. (2004) and Alani et al. (2012). $1.0 \mathrm{~g}$ of the pulverized sample 
was weighed into a $250 \mathrm{ml}$ capacity beaker of borosilicate material and $100 \mathrm{ml}$ of the ratio 3: 1 redistilled hexane:dichloromethane was added. The beaker and its content placed in the sonicator to extract the hydrocarbon for about $2 \mathrm{~h}$. The organic layer was filtered in to the $250 \mathrm{ml}$ capacity borosilicate beaker. The extract was dried by passing the filtrate through the funnel containing the anhydrous sodium sulphate. The dried extract was concentrated with a stream of nitrogen gas.

\section{Polycyclic aromatic hydrocarbon separation}

The concentrated oil was separated into the aliphatic profiles and poly aromatic hydrocarbons profiles by packing the glass column with activated alumina, neutral and activity/grade 1. Ten millilitres of the treated alumina was packed into the column and cleaned properly with distilled hexane. The extract was poured onto the alumina and was allowed to be cleaned in a $20-\mathrm{ml}$ capacity glass container. The aromatic fraction was recovered by allowing the mixture of hexane and dichloromethane in a ratio of 3 to 1 and finally removed the most polar PAH by removing with the dichloromethane into the pre-cleaned borosilicate beaker. The mixture was concentrated to $1.0 \mathrm{ml}$ by stream of the nitrogen gas before chromatography analysis. The gas chromatography conditions are as attached.

\section{Calculation of bioaccumulation factor}

The transfer factor in fish tissues from the aquatic ecosystem, which includes water and sediments, was calculated according to Kalfakakour and Akrida-Demertzi (2000) and Rashed (2001) as follows:

$$
\mathrm{BAF}=\frac{\mathrm{PAH} \text { concentration in aquatic }(\text { animal })}{\text { PAH concentration in sediment or water }}
$$

\section{Microbial analysis}

The materials used for this analysis were culture media (nutrient agar, macConkay agar, potato dextrose agar manufactured by Lab $\mathrm{M}$ and minimal salt medium adjusted to $\mathrm{pH} 7.2$ and 5.6 for hydrocarbon utilizing bacteria and fungi, respectively), aluminium foil, test tubes, sterile dilution water, mortar and pestle, weighing balance, autoclave, incubator, colony counter, sterile Petri dishes, paper tape, micropipette fitted with sterile tips gas flame, ethanol and cotton wool.

Pour plate technique was employed for the analysis of the samples collected for total bacteria count, total fungi, total coliform count, total hydrocarbon utilizing bacteria and fungi in coliform-forming unit per gram or coliform-forming unit per millilitre. One gram of the solid samples and $1 \mathrm{ml}$ of water samples were taken and diluted serially in $9 \mathrm{ml}$ of sterile water into nine folds (and, 10-9).
$0.1 \mathrm{ml}$ of each sample was inoculated into a sterile petri dish with the aid of micropipette fitted with sterile tips, and molten agars (nutrient agar, macConkay agar, potato dextrose agar manufactured by Lab $M$ and minimal salt medium) were poured and rocked (swirled) to ensure an even distribution of the inoculum. The inoculated plates were incubated for $24 \mathrm{~h}$ at $37^{\circ} \mathrm{C}$ for bacteria and 3-7 days for fungi, hydrocarbon utilizing bacteria and fungi at room temperature $\left(28{ }^{\circ} \mathrm{C}\right)$. The developed colonies were counted using colony counter and multiplied by the dilution factor to give the total number of bacteria and fungi per grams per millilitre of the samples analysed.

For hydrocarbon-utilizing bacteria and fungi isolation, sterile $9-\mathrm{cm}$ filter papers were impregnated with crude oil and were placed in the lids of inoculated plates. This allowed the crude oil vapour to condense within the plates; hence, the colonies that developed after the incubation period of $5-10$ days at room temperature $\left(28{ }^{\circ} \mathrm{C}\right)$ were recorded and multiplied by the dilution factor to give the total hydrocarbon utilizing bacteria and fungi in CFU per grams per millilitre.

\section{Examination of intestinal parasites}

Fifty fish samples each of Sarotherodon melanotheron and Chrysichthys nigrodigitatus were caught from each location and examined for intestinal helminth and protozoan parasites. Examination of fish parasites was carried out using the techniques of Akinsanya, Hassan, and Otubanjo (2007). Each fish was dissected, and the intestine of each fish was removed and placed in petri dishes containing 0.09\% normal saline. Each intestine was carefully teased open from the anterior to the posterior end to aid the emergence of the parasite. The emergence of any worm was easily noticed by its wriggling movement in the saline solution. Some of the worms however remained permanently attached with their attachment organs to the gut walls. They were carefully removed with the aid of forceps. Part of the intestine was strapped into $70 \%$ alcohol and preserved for parasitic protozoan examination. Protozoans were identified with the aid of Giemsa stain under the Dialux 20 optic microscope coupled to a video camera and connected to a PC according to the methods by Ginoris, Amaral, Nicolau, Coelho, and Ferreira (2007). The helminth parasites from each fish were then fixed in $70 \%$ alcohol in different labelled specimen bottles.

\section{Antioxidant enzyme assessment}

Oxidative enzymes were assayed in the gill and liver of the fish samples. The fishes caught from both stations were immediately dissected, and the livers and gills were 
collected into labelled sampling bottles and preserved at $4{ }^{\circ} \mathrm{C}$ prior analysis.

\section{Superoxide dismutase activity}

Superoxide dismutase (SOD) activity was determined as described Sun and Zigma (1978). The mixture (3 ml) contained $2.95 \mathrm{ml}, 0.05 \mathrm{M}$ sodium carbonate buffer $\mathrm{pH} 10.2,0.02 \mathrm{ml}$ of liver homogenates, $0.03 \mathrm{ml}$ of substrate (epinephrine) and $0.02 \mathrm{ml}$ of water. It was calculated by measuring the change in the absorbance at $480 \mathrm{~nm}$ for $5 \mathrm{~min}$.

\section{Catalase antioxidant activity assay}

This was determined as described by Aebi (1974). The mixture of $1.8 \mathrm{ml}$ of $\mathrm{H}_{2} \mathrm{O}_{2}(30 \mathrm{mM})$ was added to $0.2 \mathrm{ml}$ of the supernatant containing $10 \%$ tissue homogenate at $240 \mathrm{~nm}$ absorbance using the OPTIMA SP-3000 PLUS spectrophotometer.

\section{Glutathione (GSH)}

The reduced glutathione content was determined as described by Sedlak and Lindsay (1969). The mixture containing tissue homogenate and 10\% TCA were centrifuged. One millilitre of the supernatant was treated with $0.5 \mathrm{ml}$ of Ellman's reagent (19.8 $\mathrm{mg}$ of 5,5-dithiobisnitro benzoic acid (DTNB) in $100 \mathrm{ml}$ of $0.1 \%$ sodium nitrate) and $3.0 \mathrm{ml}$ of phosphate buffer $(0.2 \mathrm{M}, \mathrm{pH} 8.0)$. The absorbance was read at $412 \mathrm{~nm}$.

\section{Malondialdehyde}

Malondialdehyde (MDA), an index of lipid peroxidation, was determined using the method of Buege and Aust (1978). One millilitre of the supernatant was added to $2 \mathrm{ml}$ of (1:1:1 ratio) of TCA-TBA- $\mathrm{HCl}$ reagent (thiobarbituric acid 0.37\%, $0.24 \mathrm{~N} \mathrm{HCl}$ and 15\% TCA). Tricarboxylic acid-thiobarbituric acid-hydrochloric acid reagent boiled at $100{ }^{\circ} \mathrm{C}$ for $15 \mathrm{~min}$ and allowed to cool flocculent materials were removed by centrifuging at $3000 \mathrm{rpm}$ for $10 \mathrm{~min}$. The supernatant was removed, and the absorbance read at $532 \mathrm{~nm}$ against a blank MDA was calculated using the molar extinction coefficient for MDA-TBA complex of $1.56 \times 10^{5} \mathrm{M}^{-1} \mathrm{CM}^{-1}$.

\section{Histopathology}

The fish gills collected from Ibasa and Ilase were placed in separate bottles containing Bouin's fluid. After $6 \mathrm{~h}$, the fluid in each bottle was decanted and $10 \%$ phosphate-buffered formalin was added to preserve the gills. After $48 \mathrm{~h}$ of fixation, it was allowed to solidify. The blocked tissues were sectioned at $4-5 \mu \mathrm{m}$, floated into a pre-coated slides, and dried. The sections were stained using haematoxylin and eosin stains. The stained tissues were washed off in tap water and the over-stained ones destained in 1\% acid alcohol. The tissues were mounted, using DPX mountant dried and examined under the microscope. Photomicrographs were taken in the pathological laboratory of the Department of Veterinary Pathology, Faculty of Veterinary Medicine, University of Ibadan.

\section{Statistical method}

Descriptive statistics were used for the $\mathrm{PAH}$, anti-oxidative enzymes and the microbial biomass, and one sample $t$ test was used to compare the mean for the antioxidant enzymes. A bivariate correlation was used to compare the PAHs and the antioxidative enzymes in both sites (pulled as a unit) using SPSS IBM, 20.0, and Microsoft Excel, 2007, for the graphs.

\section{Results}

Bioaccumulation of PAHS in water, sediment and selected aquatic organisms in llase area of Snake Island

The results of the analysis (Table 2) show the distribution of the concentrations of PAHs, group based on molecular weight in the water, sediment and biota from the Ilase water. Sum of low molecular weight PAH (2-3 rings) which includes naphthalene, acenaphthylene, acenaphthene and fluorene had the higher concentration in the sediment, compared to high molecular weights PAH (4-6 rings), phenanthrene, anthracene, fluoranthene, pyrene, benzo(a)anthracene, chrysene, benzo(b)fluoranthene, benzo(k)fluoranthene, benzo(a)pyrene, indeno(1,2,3-cd)pyrene, dibenzo(a,h)anthracene and benzo(g,h,i)perylene. Water had higher concentrations of both low and high molecular weight PAHs (2-3 and 4-6 rings) than sediment.

Among the benthic invertebrates, the Macrobrachium vouenhovenii (prawn) recorded the highest concentration of low molecular weight PAHs, while the Penaeus notialis (pink shrimp) had the highest concentration of high molecular weight PAHs. Mugilis cephalus had the highest low molecular weight PAHs than the other fishes while Saratherodon melanotheron recorded the highest concentration of the 4-6 rings (high molecular weight) PAHs. The parasite Aspidogastrea africanus had a higher concentration of both low and high molecular weight PAHs than the Wenyonia sp. as shown in Table 2.

\section{Distribution of concentration of polycyclic aromatic hydrocarbons in water, sediment and biota in Ibasa creeks}

Table 3 shows the distribution of the concentrations of polyaromatic hydrocarbons, grouped based on molecular weight in the water, sediment and biota in the tank farm area, Snake Island, Lagos, Nigeria. Sum of the low molecular weight PAH (2-3 rings) which includes naphthalene, acenaphthylene, acenaphthene and fluorine had the higher concentration in the water medium, compared to high 
Table 2 Bioaccumulation of PAHs in water, sediment and selected aquatic organisms in llase area of Snake Island

\begin{tabular}{|c|c|c|c|c|c|c|c|c|c|c|c|c|c|}
\hline Types of PAH & $\mathrm{ng} / \mathrm{g}$ & $\mathrm{ng} / \mathrm{g}$ & WC2 & SC1 & $\mathrm{SC2}$ & $\mathrm{Ctr}$ & $\mathrm{Cn}$ & $P C$ & $\mathrm{CC}$ & SC & FC1 & FC2 & $\mathrm{FC3}$ \\
\hline \multirow[t]{6}{*}{$2-3$ rings } & NAP & NAP & 0.3 & 245.76 & 39.5 & 0.02 & 0.53 & 0.35 & 0.06 & 0.56 & 0.44 & 0.47 & 0.47 \\
\hline & ACP & $\mathrm{ACP}$ & 0.97 & 2.08 & 3.09 & 0.04 & 0.02 & 0.02 & 0.01 & 0.02 & 0.07 & 0.12 & 0.1 \\
\hline & ACE & ACE & 0.06 & 0.68 & 0.59 & 0.06 & 0.08 & 0.07 & 0.01 & 0.09 & 0.67 & 0.07 & 0.59 \\
\hline & $\mathrm{FL}$ & $\mathrm{FL}$ & 2.17 & 3.71 & 6.91 & 0.11 & 0.61 & 0.94 & 0.09 & 0.68 & 0.5 & 0.69 & 0.47 \\
\hline & PHE & PHE & 0.81 & 7.96 & 6.97 & 2.2 & 1.82 & 1.96 & 0.77 & 1.84 & 0.89 & 0.86 & 0.82 \\
\hline & SUM & 3.89 & 3.26 & 293.02 & 57.06 & 3.84 & 3.12 & 3.48 & 1.24 & 3.30 & 2.90 & 2.50 & 2.74 \\
\hline \multirow[t]{12}{*}{$4-6$ rings } & ANT & 0.62 & 0.95 & 32.83 & 31.61 & 1.41 & 0.06 & 0.14 & 0.3 & 0.11 & 0.33 & 0.29 & 0.29 \\
\hline & FLU & 0.18 & 0.5 & 3.72 & 4.61 & 1.6 & 1.27 & 0.92 & 0.53 & 1.33 & 0.39 & 0.39 & 0.41 \\
\hline & PYR & 1.23 & 4.49 & 123.24 & 100.24 & 1.71 & 0.34 & 0.3 & 0.39 & 0.35 & 0.33 & 0.37 & 0.33 \\
\hline & B(a)ANT & 0.07 & 0.29 & 3.75 & 4.16 & 0.17 & 0.01 & 0.18 & 0.03 & 0.02 & 0.08 & 0.07 & 0.08 \\
\hline & $\mathrm{CHY}$ & 0.14 & 0.47 & 7.85 & 6.05 & 0.11 & 0.03 & 0.04 & 0.03 & 0.03 & 0.08 & 0.08 & 0.07 \\
\hline & B(a)FLU & 0.09 & 0.14 & 8.59 & 7 & 0.01 & 0.03 & 0.05 & 0.01 & 0.04 & 0.04 & 0.06 & 0.04 \\
\hline & $\mathrm{B}(\mathrm{k}) F L U$ & 0.99 & 1.54 & 12.16 & 11.45 & 0.01 & 0.05 & 0.05 & 0 & 0.05 & 0.05 & 0.07 & 0.05 \\
\hline & B(a)PYR & 0.04 & 0.75 & 5.02 & 6.91 & 0.18 & 0.4 & 0.36 & 0.08 & 0.37 & 0.32 & 0.34 & 0.04 \\
\hline & IN(cd)PYR & 0 & 0.06 & 4.04 & 1.35 & 0 & 0.01 & 0.01 & 0 & 0.01 & 0.01 & 0.01 & 0.01 \\
\hline & Di(ah)ANT & 0 & 0.1 & 2.64 & 0.45 & 0.01 & 0.12 & 0.07 & 0.01 & 0.12 & 0.02 & 0.03 & 0.03 \\
\hline & B(ghi)PYL & 0.02 & 0.09 & 0.33 & 0.29 & 0.01 & 0.04 & 0.02 & 0 & 0.03 & 0.02 & 0.03 & 0.03 \\
\hline & Sum & 2.76 & 8.43 & 171.34 & 174.09 & 3.81 & 2.30 & 2.00 & 1.08 & 2.35 & 1.34 & 1.45 & 1.09 \\
\hline
\end{tabular}

Intervention values-PAHs $>40 \mathrm{mg} / \mathrm{kg}$ (sediment), $>70,000 \mathrm{ng} / \mathrm{l}$ (water)

Target values-PAHs $<1 \mathrm{mg} / \mathrm{kg}$ (sediment), $<1000 \mathrm{ng} / \mathrm{l}$ (water)

EGASPIN, 2002

Naphthalene (NAP), acenaphthalyne (ACP), acenaphthene (ACE), fluorene (FL), phenanthrene (PHE), anthracene (ANT), fluoranthene (FLU), pyrene (PYR), benzo(a)anthracene [B(a)ANT], chrysene (CHY), benzo(b)fluoranthene [B(a)FLU], benzo(k)fluoaranthene benzo(a)pyrene [B(a)PYR], indeno(1,2,3-cd)pyrene [IN(cd)PYR], dibenzo(a,h)anthracene [Di(ah)ANT], Benzo(g,h,i)perylene [B(ghi)PYL]. WC1, WC2-community water; SC1, SC2-community sediment; Ctr, $\mathrm{Cc}$-community parasites, trematode and cestode; PC, CC, SC-community prawn, crab and shrimp; FC1-Chrysichthys nigrodigitatus; FC2-Saratherodon melanotheron; FC3-Mugilis cephalus

molecular weights PAH (4-6 rings); phenanthrene, anthracene, fluoranthene, pyrene, benzo(a)anthracene, chrysene, benzo(b)fluoranthene, benzo(k)fluoranthene, benzo(a)pyrene, indeno(1,2,3-cd)pyrene, dibenzo(a,h)anthracene and benzo(g,h,i)perylene.

Water had higher concentrations of low molecular weight PAHs (2-3 rings) than sediment. While sediment recorded higher concentrations 4-6 rings PAHs than water. Among the benthic invertebrates, the Macrobrachium vouenhovenii (prawn) recorded the highest concentration of both high and low molecular weight PAHs. Saratherodon melanotheron had the highest low molecular weight PAHs than the other fishes while Mugilis cephalus recorded the highest concentration of the 4-6 rings (high molecular weight) PAHs. The parasite Wenyonia sp. had a higher concentration of both low and high molecular weight PAHs than the Aspidogastrea africanus.

\section{Distribution in concentrations of PAH residues in compartments in Snake Island, Lagos}

Tables 4 and 5 show the distributions of PAH residues in the compartments (water, sediment, benthic invertebrates, bentho-pelagic fishes and parasites) in Ilase and Ibasa communities of the Snake Island, Lagos. In the Ilase community, the sediment had the highest deposition of PAHs: total PAH, $348.00 \mathrm{ng} / \mathrm{g}$; water, $10.17 \mathrm{ng} / \mathrm{g}$; benthos, $4.53 \mathrm{ng} / \mathrm{g}$; fish, $12.02 \mathrm{ng} / \mathrm{g}$; and parasites, $6.52 \mathrm{ng} / \mathrm{g}$. Out of the total PAHs in the sediment, naphthalene (NAP) was the highest with a mean concentration of $142.63 \mathrm{ng} / \mathrm{g}$, and this is followed by pyrene (PYR), $30.96 \mathrm{ng} / \mathrm{g}$. Mean concentrations of PAH residues in the sediment range from 142.63 to $0.21 \mathrm{ng} / \mathrm{g}$; water medium range, 0.03 to $2.86 \mathrm{ng} / \mathrm{g}$; benthos, 0.01 to $1.52 \mathrm{ng} / \mathrm{g}$; fish, 0.01 to $0.86 \mathrm{ng} / \mathrm{g}$; and parasite, 0.02 to $2.01 \mathrm{ng} / \mathrm{g}$. Percentage distribution of PAHs in the compartments were water, 2.67\%; sediment, $91.28 \%$; benthos, $1.19 \%$; fish, $3.15 \%$; and parasite, $1.71 \%$. Biota-sediment accumulation factor (BSAF) for benthos, fish and parasite was $0.01,0.03$ and 0.02 , respectively.

In Ibasa, the water medium had the highest deposition of PAHs: total PAH, $571.08 \mathrm{ng} / \mathrm{g}$; sediment, $359.79 \mathrm{ng} / \mathrm{g}$; benthos, $4.65 \mathrm{ng} / \mathrm{g}$; fish, $10.20 \mathrm{ng} / \mathrm{g}$; and parasites, $6.58 \mathrm{ng} / \mathrm{g}$. Out of the total PAHs in the water, naphthalene (NAP) was the highest with a mean concentration of $538.43 \mathrm{ng} / \mathrm{g}$, and this is followed by pyrene (PYR), 
Table 3 Bioaccumulation of PAHs in water, sediment and selected aquatic organisms in Ibasa area of Lagos Lagoon

\begin{tabular}{|c|c|c|c|c|c|c|c|c|c|c|c|c|c|}
\hline Types of PAH & $\mathrm{ng} / \mathrm{g}$ & WTF1 & WTF2 & STF1 & STF2 & TFtr & TFC & PTF & CTF & STF & TFF1 & TFF2 & TFF3 \\
\hline \multirow[t]{6}{*}{$2-3$ rings } & NAP & 531.31 & 545.55 & 52.18 & 232.49 & 0.51 & 0.2 & 0.41 & 0.52 & 0.02 & 0.17 & 0.15 & 0.16 \\
\hline & $\mathrm{ACY}$ & 1.04 & 1.11 & 9.47 & 2.09 & 0.02 & 0.05 & 0.03 & 0.02 & 0.01 & 0.04 & 0.17 & 0.14 \\
\hline & ACE & 0.1 & 0.1 & 0.36 & 0.63 & 0.07 & 0.07 & 0.04 & 0.08 & 0.01 & 0.07 & 0.17 & 0.17 \\
\hline & $\mathrm{FL}$ & 2.49 & 2.41 & 12.07 & 2.44 & 0.92 & 0.09 & 0.76 & 0.79 & 0.11 & 0.08 & 0.3 & 0.3 \\
\hline & PHE & 1.08 & 1.05 & 8.58 & 8.47 & 1.82 & 2.67 & 1.47 & 1.6 & 0.61 & 2.23 & 3.75 & 3.74 \\
\hline & SUM & 540.13 & 554.91 & 113.30 & 276.57 & 3.49 & 4.31 & 3.64 & 3.09 & 1.05 & 4.27 & 6.38 & 6.33 \\
\hline \multirow[t]{12}{*}{$4-6$ rings } & ANT & 4.11 & 4.69 & 30.64 & 30.45 & 0.15 & 1.23 & 0.93 & 0.08 & 0.29 & 1.68 & 1.84 & 1.82 \\
\hline & FLU & 2.29 & 2.31 & 17.23 & 3.79 & 1.24 & 1.29 & 1.09 & 1.37 & 0.5 & 1.12 & 2.21 & 2.25 \\
\hline & PYR & 15.56 & 15.4 & 98.67 & 124.31 & 0.29 & 1.2 & 1.14 & 0.34 & 0.37 & 1.11 & 2.21 & 2.2 \\
\hline & B(a)ANT & 0.7 & 0.71 & 4.72 & 3.75 & 0.18 & 0.19 & 0.12 & 0.02 & 0.03 & 0.18 & 0.2 & 0.2 \\
\hline & $\mathrm{CHY}$ & 1.07 & 1 & 6.52 & 7.83 & 0.03 & 0.11 & 0.07 & 0.04 & 0.03 & 0.1 & 0.12 & 0.23 \\
\hline & $B(a) F L U$ & 0.99 & 1.04 & 7.05 & 8.24 & 0.05 & 0.02 & 0.01 & 0.03 & 0.01 & 0.22 & 0.02 & 0.02 \\
\hline & $B(k) F L U$ & 2.59 & 2.43 & 14.93 & 18.73 & 0.05 & 0.01 & 0.08 & 0.06 & 0 & 0.01 & 0.02 & 0.02 \\
\hline & B(a)PYR & 0.84 & 0.88 & 5.81 & 5.05 & 0.34 & 0.22 & 0.12 & 0.4 & 0.08 & 0.21 & 0.28 & 0.28 \\
\hline & IN(cd)PYR & 0.06 & 0.06 & 0.42 & 3.91 & 0.01 & 0 & 0.01 & 0.01 & 0 & 0 & 0 & 0 \\
\hline & Di(ah)ANT & 0.06 & 0.06 & 0.42 & 2.68 & 0.08 & 0.01 & 0.07 & 0.1 & 0.01 & 0.01 & 0.2 & 0.2 \\
\hline & B(ghi)PYL & 0.04 & 0.04 & 0.32 & 0.33 & 0.02 & 0.01 & 0.04 & 0.03 & 0 & 0.01 & 0.04 & 0.04 \\
\hline & SUM & 24.2 & 23.93 & 156.09 & 178.62 & 2.29 & 3.06 & 2.75 & 2.40 & 1.03 & 2.97 & 5.30 & 5.4 \\
\hline
\end{tabular}

Naphthalene (NAP), acenaphthylene (ACP), acenaphthene (ACE), fluorene (FL), phenanthrene (PHE), anthracene (ANT), fluoranthene (FLU), pyrene (PYR), benzo(a)anthracene $[B(a) A N T]$, chrysene $(C H Y)$, benzo(b)fluoranthene $[B(a) F L U]$, benzo(k)fluoaranthene benzo(a)pyrene $[B(a) P Y R]$, indeno(1,2,3-cd)pyrene [IN(cd)PYR], dibenzo(a,h)anthracene [Di(ah)ANT], benzo(g,h,i)perylene [B(ghi)PYL]. WTF1, WTF2—water; STF1, STF2—sediment; TFtr, TFc-parasites, trematode and cestode; PTF, CTF, STF-Macrobrachium vouenhoevenii (prawn), Callinectes amnicola (crab) and Penaeus notialis (shrimp); TFF1-Chrysichthys nigrodigitatus; TFF2-Saratherodon melanotheron; TFF3-Mugilis cephalus

Intervention values_-PAHs (sum of at least $10 \mathrm{PAH}$ residues) $>40 \mathrm{mg} / \mathrm{kg}$ (sediment), $>70,000 \mathrm{ng} / \mathrm{l}$ (water)

Target values-PAHs (sum of at last $10 \mathrm{PAH}$ residues) $<1 \mathrm{mg} / \mathrm{kg}$ (sediment), $<1000 \mathrm{ng} / \mathrm{l}$ (water)

EGASPIN, 2002

$111.72 \mathrm{ng} / \mathrm{g}$. Mean concentrations of PAH residues in the sediment range from 0.33 to $142.34 \mathrm{ng} / \mathrm{g}$; water medium range, 0.04 to $538.43 \mathrm{ng} / \mathrm{g}$; benthos, 0.06 to $1.96 \mathrm{ng} / \mathrm{g}$; fish, 0.05 to $9.72 \mathrm{ng} / \mathrm{g}$; and parasite, 0.03 to $4.50 \mathrm{ng} / \mathrm{g}$. Percentage distribution of PAHs in the compartments was water, $57.83 \%$; sediment, $40.07 \%$; benthos, $0.00 \%$; fish, $0.01 \%$; and parasite, $0.01 \%$. Biota-sediment accumulation factor (BSAF) for benthos, fish and parasite was $0.01,0.03$ and 0.02 , respectively.

\section{Sources and carcinogenic potential of $\mathrm{PAH}$ residues in the water-sediment media in Ilase and Ibasa creeks, Snake Island, Lagos}

Table 6 shows the source of PAHs in the aquatic environment and carcinogenic potentials of PAH residues in the water and sediment media in the Ilase community and Ibasa community. The ratio of PHE/ANT, FL/PYR and ACE/FLU in the water was Ilase community, 1.22, 0.60 and 0.12 and Ibasa community, $0.24,0.16$ and 0.04 ; and the sediment; Ilase community, $0.23,0.05$ and 0.15 and Ibasa community, 0.28, 0.07 and 0.05 . These ratios show that the source of PAH residues in both sites was pyrogenic $(<1.0)$. But dividing the sum of the high-density PAHs with the low-density PAHs gave the source index in water and sediment as 0.64 and 1.70 for the community and 22.31 and 1.16 for Ibasa community. This source index indicates that the PAH residues in the water and sediment in the Ibasa community are of the petrogenic source $(>0.1)$; this also includes the sediment of the community site, but the Ilase community water medium is of the pyrogenic source.

Carcinogenic PAH residues include benzo(a)pyrene, indeno(1,2,3-cd)pyrene and dibenzo(a,h)anthracene. The sums of carcinogenic PAHs in the water and sediment of the community were $0.48 \mathrm{ng} / \mathrm{g}$ and $10.51 \mathrm{ng} / \mathrm{g}$ and tank farm, $0.98 \mathrm{ng} / \mathrm{g}$ and $9.20 \mathrm{ng} / \mathrm{g}$, respectively. These concentrations on both sites were within the EPA limit (4 to $60 \mathrm{ng} / \mathrm{g})$. This indicates that the sediment of both sites is of high ecological risk.

\section{Microbial population distribution aquatic organisms in Ilase and Ibasa creeks, Snake Island}

Table 7 shows the microbial population in the compartments (water, sediment, benthos and fish Ilase and Ibasa creeks. In Ilase, the water had heterotrophic bacteria biomass of $3.60 \times 10^{5} \mathrm{cfu} / \mathrm{ml}$, heterotrophic fungi $2.0 \times 10^{3} \mathrm{cfu} / \mathrm{g}$, no coliforms, hydrocarbon utilizing bacteria $9.0 \times 10^{3} \mathrm{cfu} / \mathrm{g}$ and hydrocarbon-utilizing fungi $4.0 \times 10^{5} \mathrm{cfu} / \mathrm{g}$. The sediment 
Table 4 Distribution in concentrations of PAH residues in compartments In Ilase water, Snake Island

\begin{tabular}{|c|c|c|c|c|c|}
\hline Mean (sum), ng/g & Water & Sediment & Benthos & Fish & Parasite \\
\hline NAP & $0.33(0.65)$ & $142.63(285.26)$ & $0.32(0.97)$ & $0.46(1.38)$ & $0.28(0.55)$ \\
\hline $\mathrm{ACY}$ & $0.76(1.52)$ & $2.59(5.17)$ & $0.02(0.50)$ & $0.10(0.28)$ & $0.03(0.06)$ \\
\hline ACE & $0.04(0.07)$ & $0.63(1.27)$ & $0.06(0.17)$ & $0.44(1.33)$ & $0.06(0.12)$ \\
\hline $\mathrm{FL}$ & $1.72(3.43)$ & $5.31(10.62)$ & $0.57(1.71)$ & $0.55(1.66)$ & $0.36(0.72)$ \\
\hline PHE & $0.96(1.91)$ & $7.47(14.93)$ & $1.52(4.57)$ & $0.86(2.57)$ & $2.01(4.02)$ \\
\hline ANT & $0.79(1.57)$ & $32.22(64.44)$ & $0.18(0.55)$ & $0.30(0.91)$ & $1.44(2.87)$ \\
\hline FLU & $0.34(0.68)$ & $4.17(8.33)$ & $0.93(2.78)$ & $0.40(1.19)$ & $1.03(2.05)$ \\
\hline PYR & $2.86(5.72)$ & $111.74(223.48)$ & $0.40(1.19)$ & $0.34(1.03)$ & $0.09(0.18)$ \\
\hline B(a)ANT & $0.18(0.36)$ & $3.96(7.91)$ & $0.08(0.23)$ & $0.08(0.23)$ & $0.07(0.14)$ \\
\hline $\mathrm{CHY}$ & $0.31(0.61)$ & $6.95(13.9)$ & $0.03(0.10)$ & $0.08(0.23)$ & $0.74(1.47)$ \\
\hline$B(a) F L U$ & $0.12(0.23)$ & $7.8(15.59)$ & $0.03(0.10)$ & $0.05(0.14)$ & $0.02(0.04)$ \\
\hline$B(k) F L U$ & $1.27(2.53)$ & $11.81(23.61)$ & $0.03(0.10)$ & $0.06(0.17)$ & $0.03(0.06)$ \\
\hline B(a)PYR & $0.40(0.79)$ & $6.00(11.93)$ & $0.27(0.81)$ & $0.23(0.70)$ & $0.29(0.58)$ \\
\hline IN(cd)PYR & $0.03(0.06)$ & $2.60(5.39)$ & $0.01(0.02)$ & $0.01(0.03)$ & $0.01(0.01)$ \\
\hline Di(ah)ANT & $0.05(0.10)$ & $1.55(3.09)$ & $0.07(0.20)$ & $0.03(0.08)$ & $0.07(0.13)$ \\
\hline B(ghi)PYL & $0.06(0.11)$ & $0.21(0.41)$ & $0.02(0.05)$ & $0.03(0.08)$ & $0.03(0.05)$ \\
\hline Sum (mean) PAH & $10.17(0.64)^{b}$ & $348.00(21.75)$ & $4.53(0.28)^{\mathrm{a}}$ & $12.02(0.75)^{b}$ & $6.52(0.41)^{a}$ \\
\hline$\%$ concentration in compartment & 2.67 & 91.28 & 1.19 & 3.15 & 1.71 \\
\hline Biota-sediment accumulation factor (BSAF) & Nil & $\mathrm{Nil}$ & 0.01 & 0.03 & 0.02 \\
\hline
\end{tabular}

${ }^{a}$ Mean value significant at 0.05 level

${ }^{\mathrm{b}}$ Mean value significant at 0.01 level

Intervention values_PAHs (sum of at least $10 \mathrm{PAH}$ residues) $>40 \mathrm{mg} / \mathrm{kg}$ (sediment), $>70,000 \mathrm{ng} / \mathrm{l}$ (water)

Target values-PAHs (sum of at last $10 \mathrm{PAH}$ residues) $<1 \mathrm{mg} / \mathrm{kg}$ (sediment), $<1000 \mathrm{ng} / \mathrm{l}$ (water)

EGASPIN, 2002

had heterotrophic bacteria biomass of $5.0 \times 10^{6} \mathrm{cfu} / \mathrm{mg}$, heterotrophic fungi $2.0 \times 10^{3} \mathrm{cfu} / \mathrm{g}$, no coliforms, hydrocarbonutilizing bacteria $8.80 \times 10^{5} \mathrm{cfu} / \mathrm{mg}$ and hydrocarbon utilizing fungi $4.0 \times 10^{3} \mathrm{cfu} / \mathrm{g}$. Benthic invertebrates had heterotrophic bacteria biomass of $1.53 \times 10^{11} \mathrm{cfu} / \mathrm{mg}$, heterotrophic fungi $8.90 \times 10^{3} \mathrm{cfu} / \mathrm{g}$, coliforms $3.40 \times 10^{6} \mathrm{cfu} / \mathrm{g}$, hydrocarbon-utilizing bacteria $3.06 \times 10^{4} \mathrm{cfu} / \mathrm{g}$ and hydrocarbon-utilizing fungi $7.57 \times 10^{4} \mathrm{cfu} / \mathrm{g}$. Bentho-pelagic fishes had heterotrophic bacteria biomass of $2.51 \times 10^{5} \mathrm{cfu} /$ $\mathrm{g}$, no coliforms, heterotrophic fungi $1.60 \times 10^{4} \mathrm{cfu} / \mathrm{g}$, hydrocarbon-utilizing bacteria $8.79 \times 10^{4} \mathrm{cfu} / \mathrm{g}$ and hydrocarbon-utilizing fungi $2.51 \times 10^{5} \mathrm{cfu} / \mathrm{g}$ (Tables 8 and 9).

In Ibasa creek, the water had heterotrophic bacteria biomass of $7.20 \times 10^{8} \mathrm{cfu} / \mathrm{ml}$, heterotrophic fungi $1.0 \times 10^{4} \mathrm{cfu} / \mathrm{g}$, no coliforms, hydrocarbon-utilizing bacteria $2.0 \times 10^{2} \mathrm{cfu} / \mathrm{g}$ and hydrocarbon-utilizing fungi $5.80 \times 10^{3} \mathrm{cfu} / \mathrm{g}$. The sediment had heterotrophic bacteria biomass of $3.0 \times 10^{9} \mathrm{cfu} / \mathrm{g}$, heterotrophic fungi $2.0 \times 10^{2} \mathrm{cfu} / \mathrm{g}$, no coliforms, hydrocarbon-utilizing bacteria $9.90 \times 10^{5} \mathrm{cfu} / \mathrm{g}$ and hydrocarbon-utilizing fungi $4.10 \times 10^{3} \mathrm{cfu} / \mathrm{g}$. Benthic invertebrates had heterotrophic bacteria biomass of $4.71 \times 10^{11} \mathrm{cfu} / \mathrm{g}$, heterotrophic fungi $9.10 \times 10^{3} \mathrm{cfu} / \mathrm{g}$, coliforms $1.90 \times 10^{8} \mathrm{cfu} / \mathrm{g}$, hydrocarbon- utilizing bacteria $8.00 \times 10^{4} \mathrm{cfu} / \mathrm{g}$ and hydrocarbon-utilizing fungi $2.55 \times 10^{5} \mathrm{cfu} / \mathrm{g}$. Bentho-pelagic fishes had heterotrophic bacteria biomass of $9.50 \times 10^{9} \mathrm{cfu} / \mathrm{mg}$, coliforms $2.10 \times 10^{3} \mathrm{cfu} / \mathrm{g}$ heterotrophic fungi $9.29 \times 10^{2} \mathrm{cfu} / \mathrm{g}$, hydrocarbon-utilizing bacteria $7.45 \times 10^{4} \mathrm{cfu} / \mathrm{g}$ and hydrocarbon-utilizing fungi $4.37 \times 10^{5} \mathrm{cfu} / \mathrm{g}$.

\section{Parasitic infection of Chrysichthys nigrodigitatus and Sarotherodon melanotheron in Ibasa and Ilase creeks, Lagos}

Tables 10 and 11 show the prevalence of parasitic infection of Chrysichthys nigrodigitatus and Sarotherodon melanotheron in Ilase and Ibasa creeks, Lagos. Three main groups of intestinal parasites were found in the fishes sampled: protozoa, trematodes and Cestodes. The protozoa found were myxosporidial cysts from $C$. nigrodigitatus and S. melanotheron and flagellate, Lamellasoma spp. from C. nigrodigitatus. The helminths found were Aspidogastrea africanus a trematode from $C$. nigrodigitatus and Wenyonia minuta and a Cestode from S. melanotheron. The prevalence of protozoa infection, myxosporidial cyst in the Ilase community was 0.20 , Ibasa creek 0.35 and Lamellasoma spp., Ilase 0.10, none found in Ibasa creek. The rate of infestation in trematode and Cestode in Ilase 
Table 5 Distribution in concentrations of PAH residues in compartments in Ibasa creek, Snake Island, Lagos

\begin{tabular}{llllll}
\hline Sum (mean), ng/g & Water & Sediment & Benthos & Fish & Parasite \\
\hline NAP & $1076.86(538.43)$ & $284.67(142.34)$ & $0.95(0.32)$ & $0.48(0.16)$ & $0.71(0.36)$ \\
ACY & $2.15(1.08)$ & $11.56(5.78)$ & $0.06(0.02)$ & $0.35(0.12)$ & $0.07(0.04)$ \\
ACE & $0.20(1.00)$ & $0.99(0.50)$ & $0.13(0.04)$ & $0.41(0.14)$ & $0.14(0.07)$ \\
FL & $4.90(2.45)$ & $14.51(7.26)$ & $1.66(0.55)$ & $0.68(0.23)$ & $1.01(0.51)$ \\
PHE & $2.13(1.07)$ & $17.05(8.53)$ & $3.68(1.23)$ & $9.72(3.26)$ & $4.50(2.25)$ \\
ANT & $8.80(4.40)$ & $61.09(30.54)$ & $1.30(0.43)$ & $5.34(1.78)$ & $1.38(0.69)$ \\
FLU & $4.60(2.30)$ & $21.02(10.51)$ & $2.96(0.99)$ & $5.58(1.86)$ & $2.52(1.28)$ \\
PYR & $30.96(15.48)$ & $222.98(111.49)$ & $1.85(0.62)$ & $5.52(1.84)$ & $1.49(0.75)$ \\
B(a)ANT & $1.40(0.70)$ & $8.47(4.24)$ & $0.17(0.06)$ & $0.68(0.23)$ & $0.37(0.19)$ \\
CHY & $1.07(0.54)$ & $14.35(7.18)$ & $0.14(0.05)$ & $0.45(0.15)$ & $0.14(0.07)$ \\
B(a)FLU & $2.03(1.02)$ & $15.29(7.65)$ & $0.05(0.02)$ & $0.06(0.02)$ & $0.07(0.04)$ \\
B(k)FLU & $5.02(2.51)$ & $28.66(14.33)$ & $0.14(0.05)$ & $0.05(0.02)$ & $0.06(0.03)$ \\
B(a)PYR & $1.72(0.86)$ & $10.86(5.43)$ & $0.60(0.20)$ & $0.77(0.26)$ & $0.56(0.28)$ \\
IN(cd)PYR & $0.12(0.06)$ & $4.33(2.17)$ & $0.02(0.01)$ & $0.00(0.00)$ & $0.01(0.01)$ \\
Di(ah)ANT & $0.12(0.06)$ & $3.10(1.55)$ & $0.18(0.06)$ & $0.41(0.14)$ & $0.09(0.05)$ \\
B(ghi)PYL & $0.08(0.04)$ & $0.65(0.33)$ & $0.07(0.02)$ & $0.09(0.03)$ & $0.03(0.02)$ \\
Sum (mean) PAH & $571.08(36.79)$ & $359.79(25.49)^{\mathrm{a}}$ & $4.65(0.29)^{\mathrm{b}}$ & $10.20(0.64)^{\mathrm{a}}$ & $6.58(0.41)^{\mathrm{a}}$ \\
\% concentration in compartment & 57.83 & 40.07 & 0.00 & 0.01 & 0.01 \\
Biota-sediment accumulation factor (BSAF) & Nil & Nil & 0.01 & 0.03 & 0.02 \\
\hline
\end{tabular}

${ }^{\mathrm{a}}$ Mean value significant at 0.05 level

${ }^{\mathrm{b}}$ Mean value significant at 0.01 level

Intervention values-PAHs (sum of at least $10 \mathrm{PAH}$ residues) $>40 \mathrm{mg} / \mathrm{kg}$ (sediment), $>70,000 \mathrm{ng} / \mathrm{l}$ (water)

Target values-PAHs (sum of at last $10 \mathrm{PAH}$ residues) $<1 \mathrm{mg} / \mathrm{kg}$ (sediment), $<1000 \mathrm{ng} / \mathrm{l}$ (water)

EGASPIN, 2002

creek was 0.25 and 0.10 and in Ibasa creek, 0.10 and 0.20 , respectively.

\section{Antioxidants and lipid perioxidation in Ibasa and llase creeks, Snake Island, Lagos}

In the Ilase community, antioxidant enzymes in fish gills were, $\mathrm{M} \pm \mathrm{SD}$, superoxide dismutase (SOD), $57.85 \pm 39.22$, $p<0.01$; malondialdehyde (MDA), $1.15 \pm 0.56, p<0.01$; catalase (CAT), $1.72 \pm 0.22, p<0.01$; glutathione peroxidase (GPx), $0.57 \pm 0.22, p<0.01$; reduced glutathione (GSH), $0.39 \pm 0.03, p<0.01$; and glutathione $\mathrm{S}$-transferase (GST), $0.40 \pm 0.24, p<0.01$. The fish liver, $\mathrm{M} \pm \mathrm{SD}$, superoxide dismutase (SOD), $45.36 \pm 37.99$; malondialdehyde (MDA), $8.04 \pm 10.08$; catalase (CAT), $0.75 \pm 0.32, p<0.01$; glutathione peroxidase (GPx), $0.57 \pm 0.22, p<0.01$; reduced glutathione $(\mathrm{GSH}), 0.56 \pm 0.96$; and glutathione S-transferase (GST), $0.79 \pm 0.32$.

In the Ibasa community, the fish gills' antioxidant enzymes had, $\mathrm{M} \pm \mathrm{SD}$, superoxide dismutase (SOD), $48.29 \pm 12.15, p<0.01$; malondialdehyde (MDA), 1.24 $\pm 1.13, p<0.01$; catalase (CAT), $2.63 \pm 0.48, p<0.01$; glutathione peroxidase (GPx), $0.63 \pm 0.22, p<0.01$; reduced glutathione (GSH), $0.40 \pm 0.03, p<0.01$; and glutathione S-transferase (GST), $0.53 \pm 0.15, p<0.01$. The fish

Table 6 Sources and carcinogenic potential of PAH residues in the water and sediment media in llase and Ibasa creeks, Snake Island, Lagos

\begin{tabular}{|c|c|c|c|c|}
\hline \multirow{2}{*}{$\begin{array}{l}\text { EPA limit for carcinogenic PAH, } 4 \text { to } 60 \mathrm{ng} / \mathrm{g} \\
\text { Pyrogenic source }<1.0 \\
\text { Petrogenic source }>1.0\end{array}$} & \multicolumn{2}{|l|}{ Ilase creek } & \multicolumn{2}{|l|}{ Ibasa creek } \\
\hline & Water medium & Sediment & Water medium & Sediment \\
\hline Sum of carcinogenic PAH (ng/g)—B(a)PYR, IN(cd)PYR, Di(ah)ANT & 0.48 & 10.61 & 0.98 & 9.20 \\
\hline PHE/ANT & 1.22 & 0.23 & 0.24 & 0.28 \\
\hline FL/PYR & 0.60 & 0.05 & 0.16 & 0.07 \\
\hline ACE/FLU & 0.12 & 0.15 & 0.04 & 0.05 \\
\hline Sum 2-3 rings/sum of $4-6$ rings & 0.64 & 1.70 & 22.31 & 1.16 \\
\hline
\end{tabular}


Table 7 Microbial population distribution sediments, water and aquatic organisms in Ibasa and Ilase study areas, Snake Island, Lagos, llase

\begin{tabular}{|c|c|c|c|c|}
\hline & Water & Sediment & Benthic invertebrates & Bentho-pelagic fishes \\
\hline \multicolumn{5}{|l|}{ Microbes llasa } \\
\hline Heterotropic bacteria & $3.60 \times 10^{5}$ & $5.00 \times 10^{6}$ & $1.53 \times 10^{11}$ & $2.5 \times 10^{5}$ \\
\hline Coliforms & $0.0 \times 10^{6}$ & $0.0 \times 10^{4}$ & $3.40 \times 10^{6}$ & $0.0 \times 10^{6}$ \\
\hline Heterotropic fungi & $2.0 \times 10^{3}$ & $2.0 \times 10^{2}$ & $8.90 \times 10^{3}$ & $1.60 \times 10^{4}$ \\
\hline Hydrocarbon-utilizing bacteria & $9.0 \times 10^{3}$ & $8.80 \times 10^{4}$ & $3.06 \times 10^{4}$ & $8.79 \times 10^{4}$ \\
\hline Hydrocarbon-utilizing fungi & $4.00 \times 10^{5}$ & $4.0 \times 10^{3}$ & $7.57 \times 10^{4}$ & $2.51 \times 10^{5}$ \\
\hline \multicolumn{5}{|l|}{ Ibasa } \\
\hline Heterotropic bacteria & $7.20 \times 10^{8}$ & $3.00 \times 10^{9}$ & $4.71 \times 10^{11}$ & $9.50 \times 10^{9}$ \\
\hline Coliforms & $0.00 \times 10^{6}$ & $0.00 \times 10^{6}$ & $1.90 \times 10^{8}$ & $2.10 \times 10^{8}$ \\
\hline Heterotropic fungi & $1.0 \times 10^{4}$ & $2.0 \times 10^{2}$ & $9.10 \times 10^{3}$ & $9.29 \times 10^{2}$ \\
\hline Hydrocarbon-utilizing bacteria & $2.0 \times 10^{2}$ & $9.90 \times 10^{5}$ & $8.00 \times 10^{4}$ & $7.45 \times 10^{4}$ \\
\hline Hydrocarbon-utilizing fungi & $5.80 \times 10^{3}$ & $4.10 \times 10^{3}$ & $2.55 \times 10^{5}$ & $4.37 \times 10^{5}$ \\
\hline
\end{tabular}

liver, $\mathrm{M} \pm \mathrm{SD}$, superoxide dismutase (SOD), $34.51 \pm 2.27$; malondialdehyde (MDA), 6.38 \pm 6.13 ; catalase (CAT), $0.75 \pm 0.31, p<0.01$; glutathione peroxidase (GPx), $0.78 \pm$ 0.60 ; reduced glutathione $(\mathrm{GSH}), 0.42 \pm 0.10$; glutathione S-transferase (GST), $0.77 \pm 0.06, p<0.01$.

\section{Correlation of PAH residues with antioxidant enzymes and lipid perioxidationlbas in Ibasa and Ilase creeks, Lagos,} using parametric and non-parametric correlation models

Table 9 shows the correlation of PAH residues with antioxidant enzymes and lipid perioxidation in Snake Island, Lagos, using three correlation models. Of the three models, the Pearson correlation is shown to be the most suitable. Total water carcinogens (TWC) correlate with liver GPx $(r=0.967, p<0.05)$, gill catalase $(r=-0.974$, $p<0.05)$ and gill GST $(r=0.985, p<0.05)$. Low-density molecular PAHs correlate with gill GPx $(r=0.980, p<0.05)$ and liver catalase $(r=0.995, p<0.05)$. High-density molecular PAHs correlate with gill GPx $(r=0.976, p<0.05)$. In the sediment, low-density molecular PAHs correlate with liver MDA $(r=1.00, p<0.01)$. High-density PAHs correlate with liver GPx $(r=0.957, p<0.05)$, gill catalase $(r=-0.982, p<0.05)$ and gill GSH $(r=0.974$, $p<0.05)$.

\section{Histopathological alteration index in Ibasa and llase communities, Snake Island, Lagos}

Ibasa community had the greater Histopathological Alteration Index of the gills and intestines of the Chrysichthys nigrodigitatus with HAI 28.0 while community had 11.0 (Table 12). The gills had higher frequencies of tissue proliferation from partial to complete fusion of gill laminar and congestion of the blood vessels. The intestines had from mild to severe ulceration of the mucosa, obliterated villious structures and congestion of the blood vessels in the laminar propria. These are shown in Plates 1 and 2 .

\section{Discussion}

Crude oil, the mainstay of Nigerian's economy has been a major threat to the ecosystem (Amadi, Dickson, \&

Table 8 Antioxidants and lipid perioxidation in Ibasa and Ilase creeks, Snake Island, Lagos

\begin{tabular}{|c|c|c|c|c|}
\hline \multirow[t]{2}{*}{ Enzymes } & \multicolumn{2}{|l|}{ Ilase } & \multicolumn{2}{|l|}{ Ibasa } \\
\hline & Gill & Liver & Gill & Liver \\
\hline SOD & $57.85 \pm 39.22^{* *}$ & $45.36 \pm 37.99$ & $48.29 \pm 12.15^{* *}$ & $34.51 \pm 2.27^{* *}$ \\
\hline MDA & $1.15 \pm 0.56^{* *}$ & $8.04 \pm 10.08$ & $1.24 \pm 1.13^{* *}$ & $6.38 \pm 6.13$ \\
\hline CAT & $1.72 \pm 0.22^{* *}$ & $0.75 \pm 0.32^{* *}$ & $2.63 \pm 0.48^{* *}$ & $0.75 \pm 0.31^{* *}$ \\
\hline GPX & $0.57 \pm 0.22^{* *}$ & $0.61 \pm 0.75$ & $0.63 \pm 0.22^{* *}$ & $0.78 \pm 0.60$ \\
\hline GSH & $0.39 \pm 0.03^{* *}$ & $0.56 \pm 0.96$ & $0.40 \pm 0.03^{* *}$ & $0.42 \pm 0.10$ \\
\hline GST & $0.40 \pm 0.24^{* *}$ & $0.79 \pm 0.32$ & $0.53 \pm 0.15^{* *}$ & $0.77 \pm 0.06^{* *}$ \\
\hline
\end{tabular}


Table 9 Correlation of PAH residues with antioxidant enzymes and lipid perioxidation in Ibasa and llase creeks, Lagos, using parametric and non-parametric correlation models

\begin{tabular}{llll}
\hline Correlation & Pearson correlation (Rp) & Spearman's rho (Rs) & Kendall's taub (Rk) \\
\hline TWC/GPx & $0.967^{\mathrm{a}}$ (liver) & Not significant & Not significant \\
TWC/CAT & $-0.974^{\mathrm{a}}$ (gill) & Not significant & $-1.00^{\mathrm{a}}$ (gill) \\
TWC/GST & $0.985^{\mathrm{a}}$ (gill) & Not significant & Not significant \\
LW/CAT & $0.995^{\mathrm{a}}$ (liver) & Not significant & Not significant \\
LW/SOD & Not Significant & Not significant & $-1.00^{\mathrm{a}}$ (liver) \\
LW/GPX & $0.980^{\mathrm{a}}$ (gill) & Not significant & Not significant \\
HW/GPx & $0.976^{\mathrm{a}}$ (gill) & Not significant & $1.00^{\mathrm{b}}$ (gill) \\
HW/GST & Not Significant & Not significant & $-1.00^{\mathrm{b}}$ (gill) \\
LS/MDA & $1.00^{\mathrm{b}}$ (liver) & $1.00^{\mathrm{a}}$ (gill) & $1.00^{\mathrm{b}}$ (liver) \\
LS/CAT & Not Significant & $-1.00^{\mathrm{a}}$ (gill) & Not significant \\
HS/GPX & $0.957^{\mathrm{a}}$ (liver) & Not significant & Not significant \\
HS/CAT & $-0.982^{\mathrm{a}}$ (gill) & Not significant & $-1.00^{\mathrm{b}}$ (gill) \\
HS/GSH & $0.974^{\mathrm{a}}$ (gill) & Not significant & Not significant \\
HS/GST & Not significant & Not significant & $-1.00^{\mathrm{b}}$ (gill)
\end{tabular}

${ }^{\mathrm{a}}$ Significant at 0.05 level

${ }^{\mathrm{b}}$ Significant at 0.01 level

Maate, 1993). Polycyclic aromatic hydrocarbon (PAHs) are important constituents of petroleum get into the fish food chain (Amadi et al., 1993; Egborge, 1991). In this study, the sediment in Ilase community had the highest deposition of PAHs but this is not the same as Ibasa community which has 15 tank farms of petroleum industries, had the highest PAH deposition in the water medium. Comparing this with other studies, the rivers Blythe, Tyne, Wear, and Tees in North East England, total PAH concentrations of 15 parent PAHs in sediments were in excess of 10,000 ng/g dry weights (Woodhead et al., 1999). Total concentrations of 17 PAHs ranging from $107 \mathrm{ng} / \mathrm{g}$ to $1701 \mathrm{ng} / \mathrm{g}$ were reported for surface sediments of rivers and an estuary in Shanghai, China (Liu et al., 2008). In this study, PAHs had poor bioaccumulation and biomagnifications potential in the biota. Baumard et al. (1999) had suggested several other factors, such as organic matter composition, $\mathrm{pH}$ and temperature affect yields and distribution of PAHs. Lack of positive linear

Table 10 Parasitic infection of Chrysichthys nigrodigitatus and Sarotherodon melanotheron in Ibasa and llase creeks, Lagos

\begin{tabular}{lllll}
\hline Parasites & Gut parasites & Host & llase & Ibasa \\
\hline Protozoa & Myxosporidial cysts & C. nigrodigitatus & 0.20 & 0.35 \\
& & S. melanotheron & & \\
& Lamellasoma spp. & C. nigrodigitatus & 0.10 & 0.00 \\
Trematode & Aspidogastrea africanus & C. nigrodigitatus & 0.25 & 0.10 \\
Cestode & Wenyonia minuta & S. melanotheron & 0.10 & 0.20 \\
\hline
\end{tabular}

relationship between the PAHs concentrations and total organic compounds values in the sediments indicates that the PAHs were recently generated and, therefore, were yet to fully partition into organic matter in the sediments.

The total concentrations of 23 PAHs and potential carcinogenic PAHs in surface sediments from the inter-tidal areas of Dares Salaam, Tanzania, ranged from 78 to $25,000 \mathrm{ng} / \mathrm{g}$ and 5 to $11,000 \mathrm{ng} / \mathrm{g}$, respectively (Gaspare et al., 2009). In this study, the sum of low molecular weight PAH (2-3 rings) in the Ilase community had the higher concentration in the sediment. Among the congeners, naphthalene has the highest concentration in the sediment and water media in both communities. Some properties of naphthalene such as high toxicity, lower sensitivity to photo-oxidation, high persistence in water and low molecular weight make it one of the most studied congeners. Studies have shown that PAHs accumulate rapidly in aquatic animals reaching greater concentrations than in the surrounding environment, which affects the normal vital functions. Contrast to this, the biota did not accumulate more PAH. In the Ibasa community, the sum of low molecular weight PAH (2-3 rings) had the higher concentration in the water medium compared to high molecular weights $\mathrm{PAH}$ (4-6 rings). Globally, PAH concentrations ranging from 1 to $760,000 \mathrm{ng} / \mathrm{g}$, and with modal concentrations of 1000 to 10,000 have been reported for rivers, estuaries, harbors and coastal areas polluted with PAHs (Zakaria et al., 2002). 
Table 11 Prevalence of intestinal helminth parasites of Chrysichthys nigrodigitatus and Sarotherodon melanotheron in Ibasa and Ilase creeks, Snake Island, Lagos

\begin{tabular}{|c|c|c|c|c|}
\hline & Sex & Infected & Non-infected & Total (\% prevalence) \\
\hline \multicolumn{5}{|l|}{ Ilase } \\
\hline \multirow[t]{4}{*}{ Sarotherodon melanotheron } & Male & 3 & 13 & $16(64.0)$ \\
\hline & Female & 0 & 9 & $9(36.0)$ \\
\hline & Both & 3 & 22 & $25(100.0)$ \\
\hline & \multicolumn{4}{|c|}{ Chi-square $=0.198, p<0.01$} \\
\hline \multirow[t]{4}{*}{ Chrysichthys nigrodigitatus } & Male & 4 & 11 & $15(60.0)$ \\
\hline & Female & 2 & 8 & $10(40.0)$ \\
\hline & Both & 6 & 19 & $25(100.0)$ \\
\hline & \multicolumn{4}{|c|}{ Chi-square $=0.199, p<0.01$} \\
\hline \multicolumn{5}{|l|}{ Ibasa } \\
\hline \multirow[t]{4}{*}{ Sarotherodon melanotheron } & Male & 7 & 11 & $18(72.0)$ \\
\hline & Female & 3 & 4 & $7(18.0)$ \\
\hline & Both & 10 & 15 & $25(100.0)$ \\
\hline & \multicolumn{4}{|c|}{ Chi-square $=0.189, p<0.01$} \\
\hline \multirow[t]{4}{*}{ Chrysichthys nigrodigitatus } & Male & 4 & 9 & $13(52.0)$ \\
\hline & Female & 2 & 10 & $12(48.0)$ \\
\hline & Both & 6 & 19 & $25(100.0)$ \\
\hline & \multicolumn{4}{|c|}{ Chi-square $=0.145, p<0.05$} \\
\hline
\end{tabular}

Table 12 Histopathological Alteration Index in Ibasa and Ilaje communities, Snake Island, Lagos

\begin{tabular}{|c|c|c|c|c|c|c|c|c|c|c|c|c|}
\hline & \multicolumn{6}{|c|}{ Ilaje community } & \multicolumn{6}{|c|}{ Ibasa community } \\
\hline & $\mathrm{F} 1$ & F2 & F3 & F4 & F5 & $\mathrm{T}$ & F1 & F2 & F3 & $\mathrm{F} 4$ & F5 & $\bar{T}$ \\
\hline \multicolumn{13}{|l|}{$\overline{\text { GILL }}$} \\
\hline Normal (0) & 0 & 0 & 0 & - & - & 0 & 0 & 0 & - & - & - & 0 \\
\hline Hypertrophy of the epithelium (1) & - & - & - & 1 & - & 1 & - & - & 1 & - & - & 1 \\
\hline Lifting of the epithelium (1) & - & - & - & 1 & - & 1 & - & - & 1 & - & - & 1 \\
\hline Lamellar epithelial hyperplasia (1) & - & - & - & - & - & 0 & - & - & 1 & - & - & 1 \\
\hline lamellar disarray (1) & - & - & - & - & - & 0 & - & - & - & - & - & 0 \\
\hline Incomplete fusion lamellae (1) & - & - & - & 1 & - & 1 & - & - & - & - & - & 0 \\
\hline Complete fusion of all lamellae (2) & - & - & - & - & 2 & 2 & - & - & - & 2 & 2 & 4 \\
\hline Lamellar epithelium disruption (2) & - & - & - & - & 2 & 2 & - & - & - & 2 & 2 & 4 \\
\hline Congestion of the blood vessels (2) & - & - & - & & 2 & 2 & - & - & - & 2 & 2 & 4 \\
\hline Uncontrolled proliferation of tissue (3) & - & - & - & - & - & 0 & - & - & - & - & 3 & 3 \\
\hline Necrosis (4) & - & - & - & - & - & 0 & - & - & - & - & - & 0 \\
\hline \multicolumn{13}{|l|}{ Intestine } \\
\hline Normal, no parasites, ova (0) & 0 & 0 & 0 & 0 & - & 0 & 0 & 0 & 0 & - & - & 0 \\
\hline Mild ulceration of mucus (1) & - & - & - & - & 1 & 1 & - & - & - & 1 & - & 1 \\
\hline Inflammatory cells (1) & - & - & - & - & 1 & 1 & - & - & - & 1 & - & 1 \\
\hline Absence of globlet glands (2) & - & - & - & - & - & 0 & - & - & - & - & - & 0 \\
\hline Presence of debris in lumen (2) & - & - & - & - & - & 0 & - & - & - & - & 2 & 2 \\
\hline Moderate congestion of the blood vessel (3) & - & - & - & - & - & 0 & - & - & - & - & 3 & 3 \\
\hline Obliterated villious structures (3) & - & - & - & - & - & 0 & - & - & - & - & 3 & 3 \\
\hline Severe ulceration of mucus (4) & - & - & - & - & - & 0 & - & - & - & - & - & 0 \\
\hline Histopathological Alteration Index (HAI) & 0 & 0 & 0 & 3 & 8 & 11 & 0 & 0 & 3 & 8 & 17 & 28 \\
\hline
\end{tabular}




\section{INTESTINE}
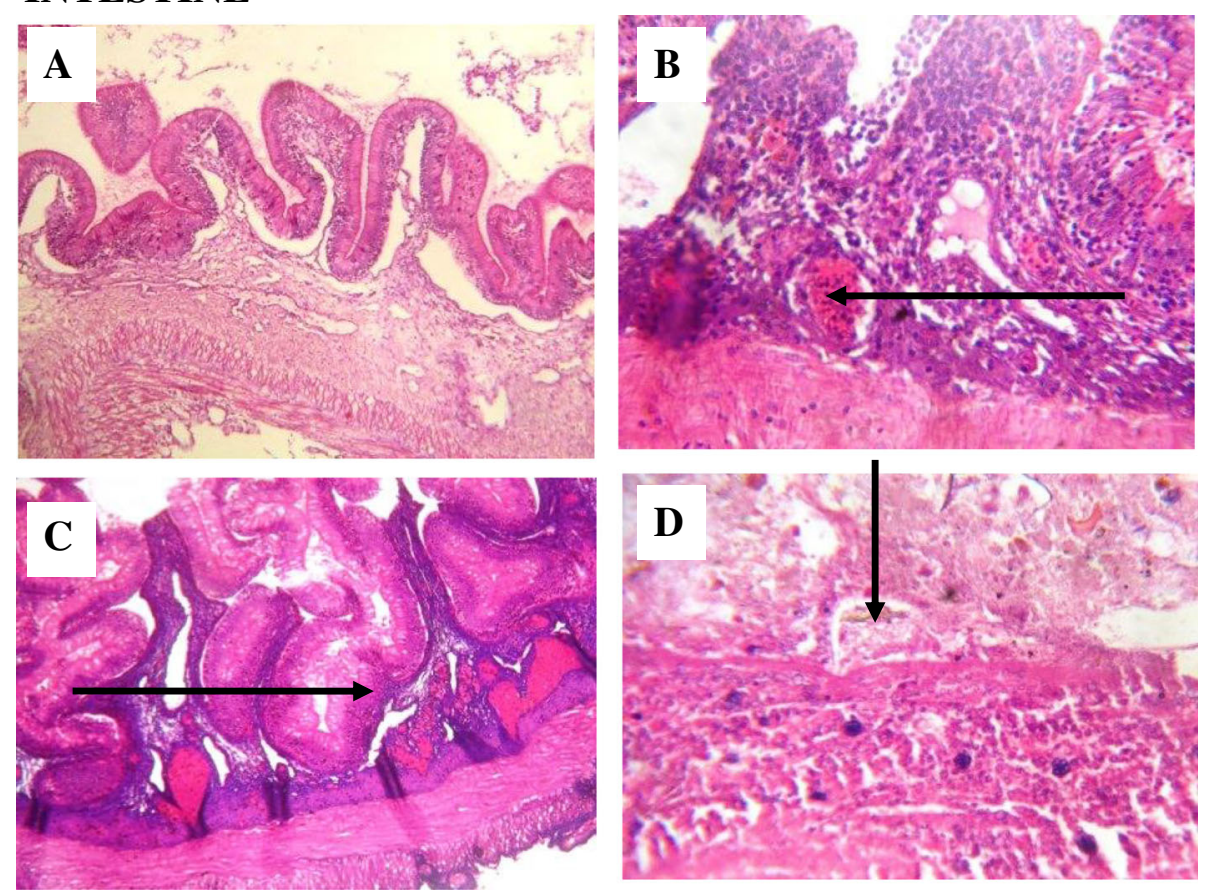

Plate $1 \mathbf{a}$ The sections of the intestine show no significant lesion. No parasite is seen. $\mathbf{b}$ The sections of the intestine show a slight congestion of the blood vessels in the laminar propia. c The sections of the intestine show moderate congestion of the blood vessels in the laminar propia. No parasite is seen. $\mathbf{d}$ Sections of the intestine show the villious structures completely obliterated and presence of debris (black arrow) in the lumen. No parasite is seen $\times 100$

PAH composition in sediments and water may be used to characterize and identify the sources of contamination by multivariate statistical tools or diagnostic ratios between specific compounds (Baumard et al., 1998; Zakaria et al., 2002; Ma et al., 2005; Liu et al., 2008). The main anthropogenic sources of PAHs include the incomplete combustion of fossil fuels and other organic substances (pyrogenic) and also as components of crude oil and its refined products (petrogenic). The ratios of Phen/Ant and Flu/Pyr have been used extensively to distinguish petrogenic and pyrogenic sources (Baumard et al., 1998). In this study, the ratios of PHE/ANT, FL/PYR and ACE/FLU in the water were less than 1 . These ratios show that the source of PAH residues in both sites was pyrogenic $(<1.0)$. This source index indicates that the PAH residues in the water and sediment in Ibasa area are of the petrogenic source $(>0.1)$; this includes the sediment of the Ilase community, but Ilase water medium is of the pyrogenic source. These values suggest a pyrogenic source for the PAHs in the sediments. The PAHs in the sediments are believed to have resulted from the effects of incomplete combustion of fossil fuels in generators used by the industries and residential houses very close to the lagoon, with occasional forest fires in the adjoining mangrove forests that border the lagoon.
The natural oil seeps have been linked to the local presence of hydrocarbon-eating microorganisms (Kemsley, 2012; Head, Jones, \& Röling, 2006), a fact that an advantage in the case of an accidental oil spill (Kemsley, 2012; Valentine et al., 2012). The role of microorganisms in the degradation of contaminants in the aquatic environment can not be over emphasized. Degradation of heavy to light, complex to simple hydrocarbons by microorganisms had been reported by Atlas (2011). In this study, the biomass hydrocarbon utilizers (bacteria and fungi) correlate with $\mathrm{pH}(r=-0.959, p<0.05)$; they were found more abundant at the Ibasa community, which had greater PAHs concentrations.

Research on PAHs concentration in the environment has received much attention from scientists and regulators due to their persistent and toxic properties (IARC, 1983; NRC, 1983). They are known to accumulate in sediments, aquatic pelagic and benthic food webs and pose a risk to human health (Malins et al., 1988; Baumard et al., 1998; Law \& Klungsoyr, 2000). There are fractions of the crude oil that are water soluble and toxic to aquatic organisms. Some PAHs have been known as carcinogenic. This includes benzo(a)pyrene, indeno(1,2,3-cd)pyrene and dibenzo(a,h)anthracene. The water and sediment of Ibasa area had greater carcinogenic potential. Since some of these compounds 


\section{GILLS}
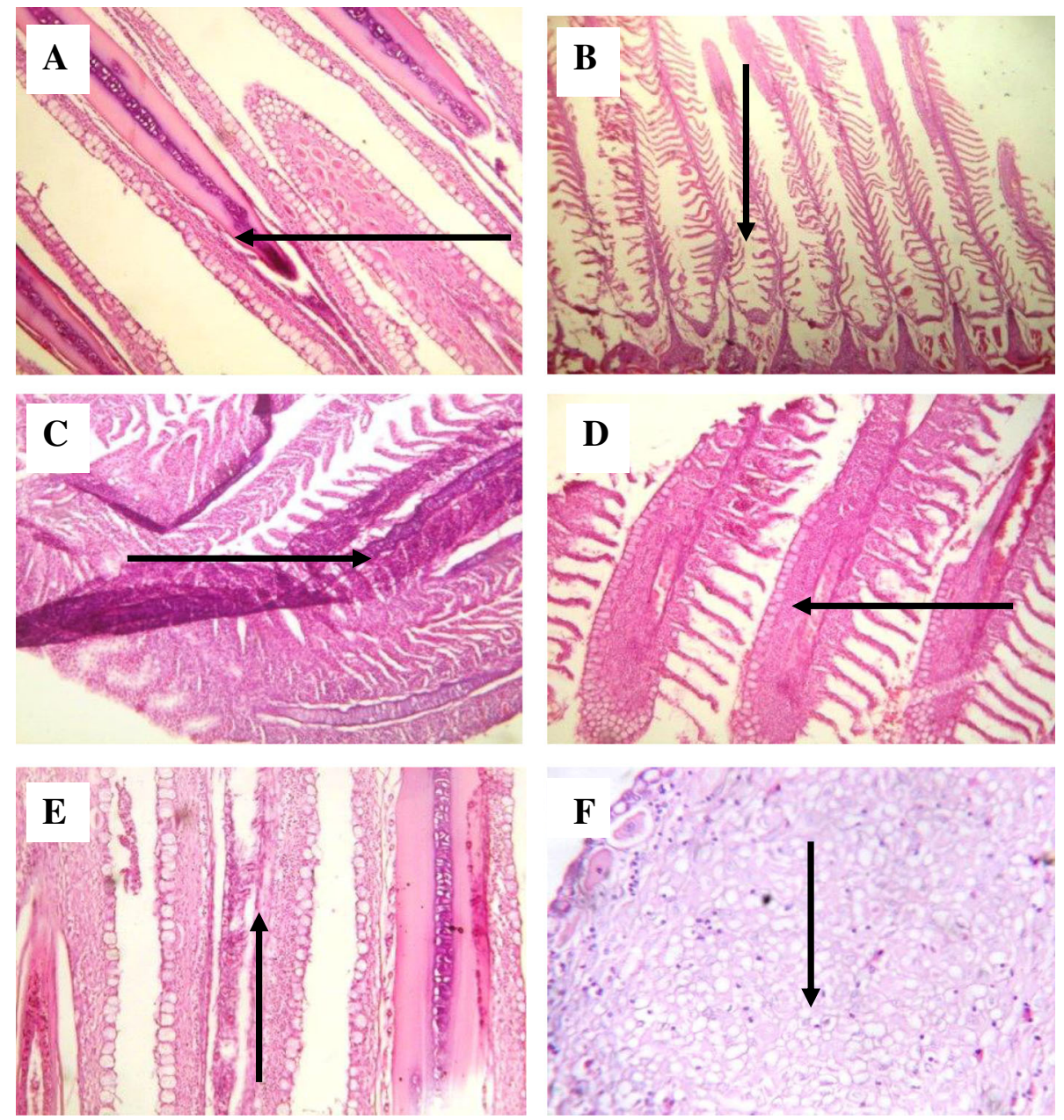

Plate $\mathbf{2}$ a The sections of the gill show hyperplasia of the lamella epithelium and mucous cells and partial fusion of secondary lamella, focal loss of secondary lamella and a focal area of degeneration (black arrow). $\mathbf{b}$ The sections of the gill show focal area of mucous cells hyperplasia. $\mathbf{c}$ The sections of the gill show fusion of the secondary lamella. $\mathbf{d}$ The sections of the gill show complete fusion of the secondary lamella as well as mild vascular dilation and congestion. e The sections of the gill show congestion and hyperplasia of the mucous cells. $\mathbf{f}$ Loss of secondary lamella $\times 100$

are well-known carcinogens and mutagens (Binelli \& Provini, 2003), these contaminant classes have been generally regarded as a high priority for the environmental pollution monitoring.

Biomonitoring entails measuring changes in biological systems in response to perturbations of their environment. These alterations can be wide-ranging and may be physical in nature such as habitat destruction or chemical from specific pollutants. An important characteristic of a biomonitor is that it only detects bioavailable changes, which impact on the biological system being monitored. Parasites have been highly reported as indicators of pollution. Parasites are affected by environmental changes in different ways; thus, information on parasites can indicate anthropogenic impacts (Lafferty, 1997). They often interact in a complex way with other stressors (Lafferty, 1997). Ibasa area had a greater prevalence of myxosporidial cyst, parasitic protozoa. Cysts in the gut may induce metaplastic proliferation of the infected host tissue and become infiltrated by the capillary network. In this study, there was a detachment of villi from the mucosal basement and marked the absence of goblet glands due to the damage done to the mucosa and burst of the epithelial cells. Large cysts or large aggregates of small cysts may possibly cause some mechanical damage as seen in the study.

Gills are very important in respiration, acid-base balance, osmoregulation and excretion of nitrogenous wastes in fish, and they include the greatest surface 
area of the aquatic organisms in contact with the external environment. They are also an important way of uptake of a pollutant into the organism; thus, the gills are the first site where petroleum hydrocarbon-induced lesions may occur. Therefore, their morphology can be very useful as a bioindicator in environmental evaluation. Bioaccumulation and magnification of these contaminants along the aquatic food chain end up in the gastrointestinal tract of the fish, a top trophic predator. This could induce parasitic infestation of the intestine. Alterations in the intestine had been reported as a bioindicator of multi-stress (Akinsanya et al., 2015; Ukwa, 2012). Natural populations of fish can develop elevated tolerances to certain environmental contaminants, but exposure must be at tolerable concentrations in order for this phenomenon to be triggered. There were greater responses among fishes in the Ibasa community compared to the Ilase community. There was no much difference in antioxidant responses but much difference in the pathological alterations as shown in this study. Ibasa had the greater Histopathological Alteration Index of the gills and intestines of the fish. The gills had higher frequencies of tissue proliferation, from partial to complete fusion of gill laminar, and congestion of the blood vessels. The intestines had from mild to severe ulceration of the mucosa, obliterated villious structures and congestion of the blood vessels in the laminar propia.

\section{Conclusions}

In conclusion, the Ilase community had the highest deposition of PAHs in the sediment, but this is not the same as the Ibasa community that had the highest PAH deposition in the water medium. These concentrations on both sites were within the EPA limit $(<1000 \mathrm{ng} / \mathrm{g})$. This indicates that the sediment and water on both sites were of moderately low ecological risk. Ibasa had greater hydrocarbon utilizers, parasitic protozoa prevalence and carcinogenic potential. The Ibasa community also showed the greater biological effect having HAI of 28.0 compared to the Ilaje community with HAI of 11.0. The PAH residues in the water and sediment in Ibasa is of the petrogenic source $(>0.1)$; this includes the sediment of the Ilase community, but water medium is of the pyrogenic source. These residues are known to accumulate in sediments, especially anaerobic sediments as well as in crabs, shrimps and other aquatic invertebrates through which they could get into bentho-pelagic food chain and food webs and could pose a significant risk to human health. As a result of this, continuous monitoring is highly advised.

\section{Abbreviations}

BAF: Bioaccumulation factor; BOD: Biochemical oxygen demand: BSAF: Biota-sediment accumulation factor; CAT: Catalase; CFU: Coliform forming unit; $\mathrm{CHCl}_{3}$ : Trichloromethane; DPR: Department of Petroleum Resources; DTNB: 5,5-Dithiobisnitro benzoic acid; GPx: Glutathione peroxidase; GSH: Reduced glutathione; GSTs: Glutathione S-transferase; $\mathrm{H}_{2} \mathrm{O}_{2}$ : Hydrogen peroxide; $\mathrm{H}_{2} \mathrm{SO}_{4}$ : Sulphuric acid; HAl: Histopathological Alteration Index; $\mathrm{HCl}$ : Hydrogen chloride; $\mathrm{HNO}$ : Nitric acid; $\mathrm{KH}_{2} \mathrm{PO}_{3}$ : Sodium phosphate; MDA: Malondialdehyde; $\mathrm{NaOH}$ : Sodium hydroxide; $\mathrm{PAH}$ : Polyaromatic hydrocarbon; $\mathrm{SnCl}_{2}$ : Tin (II) chloride; SOD: Superoxide dismutase; TBA: Tricarboxylic acid; TCA: Thiobarbituric acid

\section{Acknowledgements}

We are grateful to Prof. J.K Saliu, University of Lagos, who helped edit the manuscript and the reviewers for the comments and suggestions that improved the paper.

\section{Availability of data and materials}

All data presented are original and are available on request. Data can be found at the Department of Zoology Archive, 2015 batch, University of Lagos.

\section{Authors' contributions}

The field and laboratory work were performed by TA and UU and supervised by Dr. BA and Dr. SA. Correspondence and manuscript drafting were done by Dr. BA assisted by UU. All authors read and approved the final manuscript.

\section{Competing interest}

The authors declare that they have no competing interests.

\section{Ethics approval and consent to participate}

There is presently no ethical committee on the use of fish for research purposes in Nigeria, but this study is in compliance with international guidelines for the fish use and handling.

\section{Consent for publication}

The manuscript does not contain any individual person's data.

\section{Publisher's Note}

Springer Nature remains neutral with regard to jurisdictional claims in published maps and institutional affiliations.

\section{Author details}

'Parasitology and Bioinformatics Unit, Department of Zoology, University of Lagos, Akoka, Nigeria. ${ }^{2}$ Department of Microbiology, University of Lagos, Akoka, Nigeria. ${ }^{3}$ Ecotoxicology Unit, Department of Zoology, University of Lagos, Akoka, Nigeria.

Received: 1 August 2017 Accepted: 30 July 2018

Published online: 30 October 2018

\section{References}

Abdel-Gaber, R., Abdel-Ghaffar, F., Bashtar, A. R., Morsy, K., \& Saleh, R. (2016). Interaction between the intestinal parasite Polyonchobothrium clarias (Cestode: Ptychobothriidae) from African sharptooth catfish, Clarias gariepinus and heavy metal pollutants in an aquatic environment in Egypt. Journal of Helminthology, 30, 1-8.

Abdel-Ghaffar, F., Badr, A. M., Morsy, K, Ebead, S., El-Deeb, S., Al-Quraishy, S., \& Mehlhorn, H. (2015a). Cytokine signature and antibody-mediated response against fresh and attenuated Anisakis simplex (L3) administration into Wistar rats; implication for anti-allergic reaction. Parasitological Resources, 114(8), 2975-2984.

Abdel-Ghaffar, F., Abdel-Gaber, R., Bashtar, A. R., Morsy, K., Mehlhorn, H., Al-Quraishy, S., \& Saleh, R. (2015b). Hysterothylacium aduncum (Nematoda, Anisakidae) with a new host record from the common solea (Soleidae) and the role as a biological indicator of pollution. Parasitological Resources, 114(2), 513-522.

Abdelsalam, M., Abdel-Gaber, R., Mahmoud, M. A., Mahdy, O. A., Khafaga, N. I. M., \& Warda, M. (2015). Morphological, molecular and pathological appraisal of Callitetrarhychus gracilis plerocerci (Lacistorhynchidae) infecting Atlantic little tunny (Euthynnus alletteratus) in Southern Mediterranean. Journal of Advanced Research, 7(2), 317-326. 
Abdolahpur Monikh, F., Hosseini, M., Kazemzadeh Khoel, J., \& Ghasemi, A. F. (2014). Polycyclic Aromatic Hydrocarbons levels in sediment, benthic, benthopelagic and pelagic fish species from Persian Gulf. Int. J. Environ. Res., 8(3), 839-848.

Achten, C., \& Hofmann, T. (2010). Umweltrelevanz von natülichen polyzyklischen aromatischen kohlenwassertoffen aus steinkohlen- eine übersicht. Grundwasser, 15, 518.

Aebi, H., 1974. Catalase in Bergmeyer Hans Ulrich, 5th Edition, "Methods of Enzymatic Analysis", Academic Press Incorporated, New York, USA, pp: 273-278.

Ajagbe WO, Omokehinde OS, Alade AA, Agbede OA 2012. Effect of crude oil impacted sand on compressive strength of concrete Construction and Building Materials 26: 9-12.

Akinsanya, B., Hassan, A. A., \& Otubanjo, O. A. (2007). A comparative study of the parasitic helminth fauna of Heterotis niloticus (Osteoglossidae) and Gymnarchus niloticus (Gymnarchidae) from Lekki Lagoon, Lagos, Nigereia. Pakistan J. Biology, 10(3), 427-432.

Akinsanya, B., Kuton, M. P., Oyebola, L., Saliu, J. K., \& Ukwa, U. D. (2015). Condition factor and Gastro-intestinal Parasites of fish as indicators of stress in Lekki lagoon, Lagos, Nigeria. Egyptian Academic Journal of Biological Science (E Medical Entomology and Parasitology), 7(1), 1-13.

Akinsanya, B., Ukwa, U. D., \& Hassan, A. A. (2014). Effect of Host Condition on intestinal parasite load and prevalence in Malapterurus electricus, Gmelin 1789, (Siluriformes: Malapteridae) In Lekki Lagoon, Lagos, Nigeria. Nigeria Journal of Parasitology, 35, 59-64.

Alani, R., Drouillard, K., Olayinka, K., \& Alo, B. (2012). Bioaccumulation of polycyclic aromatic hydrocarbons in fish and invertebrates of Lagos lagoon, Nigeria. Journal of Emerging Trends in Engineering and Applied Sciences, 3(2), 287-296.

Amadi, A. A., Dickson, A., \& Maate, G. O. (1993). Remediation of oil polluted soil. Effect of organic and inorganic nutrient supplement on performance of maize (Zea mays L). Water Air Soil Pollution, 66, 59-76.

Amaeze, N. H., Egonmwan, R. I., Jolaoso, A. F., \& Otitoloju, A. A. (2012). Coastal environmental pollution and fish species diversity in Lagos lagoon, Nigeria. Intl J Env Prot, 2, 8-16.

Atlas, R. M. (2011). Oil biodegradation and bioremediation: A tale of the two worst spills in U.S. history. Environmental Science \& Technology, 45, 6709-6715.

Avenant-Oldewage, A. 2001. Protocol for the assessment of fish health index. Report No. 2001/03/31. BIOM. GEN. (HT), Rand Water Vereeniging.

Ayola, S. O., Olorunsanmi, G. T., \& Oke, A. O. (2017). Comparative Assessment of Total Hydrocarbon Content and Bioaccumulation of heavy metals in Sarotherodon melanotheron at Atlas Cove Area and Okobaba of Lagoon Lagoon. Iranian Journal of Energy and Environment, 8(2), 152-159.

Balogun, K. J., Ladigbolu, I. A., \& Ariyo, A. A. (2011). Ecological assessment of a coastal shallow lagoon in Lagos, Nigeria: a bio-indicator approach. J App/ Sci Environ Manage, 15, 41-46.

Banaee, M., Mirvagefei, A. R., \& Amiri, B. M. (2008). Effect of sub-lethal diazinon concentrations on blood plasma biochemistry. Int.J.Environ. Res., 2, 189-198.

Baumard, P., Budzinski, H., Garrigues, P., Narbonne, J. F., Burgeot, T., \& Miche, X. (1999). Polycyclic aromatic hydrocarbon (PAH) burden of mussels (Mytilus sp.) in different marine environments in relation with sediment PAH contamination and bioavailability. Marine Environmental Research, 47, 415-439.

Baumard, P., Budzinski, H., Michon, Q., Garrigues, P., Burgeot, T., \& Bellocq, J. (1998). Origin and bioavailability of PAHs in the Mediterranean sea from mussel and sediment records. Estuar. Coast. Shelf S., 47, 77-90.

Beyer, J., Borgenvik, E., \& Ravn, H. K. (1998). Bioavailability of PAH in effluent water from an aluminium works evaluated by transplant caging and biliary fluorescence measurements of Atlantic cod (Gadus morhua L.). Marine Environmental Research, 46, 233-236.

Binelli, A., \& Provini, A. (2003). POPs in edible clams from different Italian and European markets and possible human health risk. Mar. Poll. Bull., 46, 879-886.

Boonyatumanond, R., Murakami, M., Wattayakorn, G., Togo, A., \& Takada, H. (2007). Sources of polycyclic aromatic hydrocarbons (PAHs) in street dust in a tropical Asian mega-city, Bangkok, Thailand. Sci Total Environ, 384, 420-432.

Botello, A. V., Calva, L. G. B., \& Ponce-Velez, G. (2001). Polycyclic aromatic hydrocarbons in sediments from coastal lagoons of Veracruz state, Gulf of Mexico. Bulletin of Environmental Contamination and Toxicology, 67, 889-897.

Brophy, P. M., \& Pritchard, D. I. (1992). Metabolism of lipid peroxidation products by the gastrointestinal nematodes Necator americanus, Ancyclostoma ceylanicum, and Heligmosomoides polgyrus. Int.J.Parasitol, 22, 1009-1021.

Buege, J. A., \& Aust, S. D. (1978). Microsomal Lipid Peroxidation. Methods in Enzymology, 52, 302-312.
Carlander, K. (1969). Handbook of freshwater fishery biology, (vol. 1). Ames: lowa State University Press.

Correa, M., \& Gracia, H. I. (1990). Physiological responses of juvenile white mullet, Mugil cephalus exposed to benzene. Bull.Environ.Contam.Toxicol, 44, 428-434.

Durand, C., Ruban, V., \& Amblès, O. A. (2004). Characterization of the organic matter of sludge: Determination of lipids, hydrocarbons and PAHs from road retention/infiltration ponds in France. Environmental Pollution, 132, 375-384.

Dzik, J. M. (2006). Molecules released by helminth parasites involved in host colonization. Acta Biochemica Polonia, 53, 33-64.

Egborge, A. B. M. (1991). Industrialization and heavy metal Pollution in Warri River. $32^{\text {nd }}$ Inaugural lecture, (p. 32). Benin City: University of Benin.

FAO/SIDA (1986). Mannual methods in aquatic environmental research, part 9, Analysis of metals and organochlorines in fish. FAO fish/Technology, 9, 212-214.

Feng, X., \& Pisula, W. (2009). Large polycyclic aromatic hydrocarbons: Synthesis and discotic organization. Pure and Applied Chemistry, 81, 2203-2224.

Gaspare, L., Machiwa, J. F., Mdachi, S. J. M., Streck, G., \& Brack, W. (2009). Polycyclic aromatic hydrocarbon (PAH) contamination of surface sediments and oysters from the inter-tidal areas of Dar es Salaam, Tanzania. Environ. Pollut, 157, 24-34.

Ginoris, Y. P., Amaral, A. L., Nicolau, A., Coelho, M. A. Z., \& Ferreira, E. C. (2007). Development of an image analysis procedure for identifying protozoa and metazoan typical of activated sludge system. Water Research, 41, 2581-2589.

Harvey, R. G. (1996). Polycyclic aromatic hydrocarbons, (p. 120). New York: Wiley-VCH.

Head, I. M., Jones, D. M., \& Röling, W. F. M. (2006). Marine microorganisms make a meal of oil. Nature Reviews. Microbiology, 4, 173-182.

Hecker, M., \& Karbe, L. (2005). Parasitism in fish-an endocrine modulator of ecological relevance? Aquatic Toxicology, 72, 195-207.

Hites, R. A., Laflamme, R. E., \& Windsor Jr., J. G. (1980). Polycyclic aromatic hydrocarbons in an anoxic sediment core from the Pettaquamscutt River (Rhode Island, USA). Geochimica et Cosmochimica Acta, 44, 873-878.

IARC (1983). IARC Monographs on the Evaluation of the Carcinogenic Risk of Chemicals to Humans, Polynuclear Aromatic Compounds, Part 1, Chemical, Environmental and Experimental Data, Lyon (vol. 32, pp. 239-245).

Kalfakakour V, Akrida-Demertzi K (2000). Transfer factors of heavy metals in aquatic organisms of different trophic levels. In: HTML publications. 1: 768-786.

Kemsley, E. R. (2012). Water eased oil removal in Gulf. Chemical and Engineering News, 6, 32-33.

Lafferty, K. D. (1997). Environmental parasitology: what can parasites tell us about human impacts on the environment? Parasitology Today, 13, 251-255.

Lang, K. F., \& Buffleb, H. K. (1964). Fulminen (1,2-benzo-picen) im steinkohlenteer. Chemische Berichte, 97, 494-497.

Laughlin, R. B., \& Neff, J. M. (1979). Interactive effects of salinity, temperature and polycyclic aromatic hydrocarbons on the survival and development rate of larvae of the mud crab Rhithropanopeus harrisii. Marine Biology, 53, 281-291.

Law, R. J., \& Klungsoyr, J. (2000). The analysis of polycyclic aromatic hydrocarbons in marine samples. Int. J. Environ. Pollution, 13, 262-283.

Liu, Y., Chen, L., Jianfu, Z., Qinghui, H., Zhiliong, Z., \& Hongwen, G. (2008). Distribution and source of polycyclic aromatic hydrocarbons in surface sediments of rivers and an estuary in Shanghai. China Environ. Pollut., 154, 298-305.

Ma, L. L., Chu, S. G., Wang, X. T., Cheng, H. X., Liu, X. F., \& Xu, X. B. (2005). Polycyclic aromatic hydrocarbons in the surface soils from outskirts of Beijing, China. Chemosphere, 58, 1355-1363.

Malins, D. C., McCain, B. B., Landahl, J. T., Myers, M. S., Krahn, M. M., \& Brown, D. W. (1988). Neoplastic and other diseases in fish in relation to toxic chemicals: an overview. Aquatic Toxicology, 11(1-2), 43-67.

Mascarelli, A. (2010). After the oil. Nature, 467, 22-24.

Munkittrick, K. R., \& Dixon, P. G. (1998). Growth, fecundity and energy stores of white sucker (Catostomus commersoni) from lakes containing elevated levels of coppered. Canadian Jounrnal of Fisheries and Aquatic Sciences, 45, 1355-1365.

Næs, K., \& Oug, E. (1998). The distribution and environmental relationships of polycyclic aromatic hydrocarbons (PAHs) in sediments from Norwegian smelter-affected fjords. Chemosphere, 36(3), 561-576.

NRC (National Research Council) (1983). Risk Assessment in the Federal Government: Managing the Process. Washington: National Academy Press.

Palm H.P.D., 2011. Fish parasites as biological indicators in a changing world: Can we monitor environmental impact and climate change? Progress in Parasitology, Parasitology Research Monograph.

Pothuluri, J. V., \& Cerniglia, C. E. (1994). Microbial metabolism of polycyclic aromatic hydrocarbons. In G. R. Chaudhry (Ed.), Biological degradation and bioremediation of toxic chemicals, (p. 92124). London: Chapman \& Hall.

Poulin (1992). Determinants of host-specificity in parasites of freshwater fishes. Int.J.Parasitol., 22, 753-761. 
Rashed MN (2001). Monitoring of environmental heavy metals in fish from Nasser Lake. Environ. Int. 27: 27-33.

Redondo, J. M., \& Platonov, A. K. (2009). Self-similar distribution of oil spills in European coastal waters. Environmental Research Letters, 4, 14008.

Riggs, M. R., Lemly, A. D., \& Esch, G. W. (1987). The growth, biomass and fecundity of Bothriocephalus acheilognathi in a North Carolina cooling reservoir. The Journal of Parasitology, 73, 893-900.

Røe Utvik, T. (1999). Chemical characterization of produced water from four offshore oil production platforms in the North Sea. Chemosphere, 39, 2593-2606.

Sedlak, J., \& Lindsay, R. H. (1969). Estimation of Total Protein-Bound, and Nonprotein Sulfhydryl Groups in Tissues with Ellman's Reagent. Analytical Biochemistry, 25, 1192-1205.

Smith, J. N., \& Levy, E. M. (1990). Geochronology for polycyclic aromatic hydrocarbon contamination in sediments of the Saguenay Fjord. Environmental Science \& Technology, 24, 874-879.

Sogbanmu, T. O., Nagy, E., Philips, D. H., Arlt, V. M., Otitoloju, A. A., \& Bury, R. N. (2016). Lagos lagoon sediment organic extract and polycyclic aromatic hydrocarbons induce embryotoxic, teratogenic and genotoxic effects in Danio rerio (zebra fish) embryos. Environ.Sci.Pollut.Res, 23, 14489-14501.

Sun, M., \& Zigma, S. (1978). An Improved Spectrophotometer Assay of Superoxide Dismutase based on Epinephrine Antioxidation. Analytical Biochemistry, 90, 81-89.

Sures, B. (2004). Environmental Parasitology: relevancy of parasites in monitoring environmental pollution. Trends in Parasitology, 20, 170-177.

Ukwa, U. D. (2012). DNA Bar-coding, Morphometric and Meristic features, Biochemical Composition And Metal Accumulation in Malapterurus electricus and Its Intestinal Parasites in Lekki lagoon, Lagos, Nigeria, M.Sc Thesis (p. 128) Department of Zoology, University of Lagos.

Valentine, D. L., Mezić, I., Maćešić, S., Crnjarić-Ž̌ic, N., Ivić, S., Hogan, P. J., ... Loire, S. (2012). Dynamic autoinoculation and the microbial ecology of a deep water hydrocarbon irruption. Proceedings of the National Academy of Sciences of the United States of America.

Wakeham, S. G., Schaffner, C., \& Giger, W. (1980). Polycyclic aromatic hydrocarbons in recent lake sediments- I. Compounds having anthropogenic origins. Geochim. Cosmo. Acta, 44, 403-413.

Woodhead, R. J., Law, R. J., \& Matthiessen, P. (1999). Polycyclic aromatic hydrocarbons in surface sediments around England and Wales, and their possible biological significance. Marine Pollut. Bull, 38, 773-790.

Zakaria, M. P., Takada, H., Tsutsumi, S., Ohno, K., Yamada, J., Kound, E., \& Kumata, H. (2002). Distribution polycyclic aromatic hydrocarbons (PAHs) in rivers and estuaries in Malaysia: a widespread input of petrogenic PAHs. Environ Science and Technology, 36, 1907-1918.

\section{Submit your manuscript to a SpringerOpen ${ }^{\circ}$ journal and benefit from:}

- Convenient online submission

- Rigorous peer review

- Open access: articles freely available online

High visibility within the field

- Retaining the copyright to your article

Submit your next manuscript at $\boldsymbol{\nabla}$ springeropen.com 